\title{
IPO Behavior in GCC Countries: Goody-Two Shoes or Bad-to-the-Bone?
}

Abdullah Al-Hassan, Fernando Delgado, and Mohammed Omran 



\title{
IMF Working Paper
}

Middle East and Central Asia Department

IPO Behavior in GCC Countries: Goody-Two Shoes or Bad-to-the-Bone?

Prepared by Abdullah Al-Hassan, Fernando Delgado, and Mohammed Omran

Authorized for distribution by Ahsan H. Mansur

July 2007

\begin{abstract}
This Working Paper should not be reported as representing the views of the IMF.

The views expressed in this Working Paper are those of the author(s) and do not necessarily represent those of the IMF or IMF policy. Working Papers describe research in progress by the author(s) and are published to elicit comments and to further debate.

This paper documents the phenomenon of underpricing initial public offerings (IPOs) for 47 firms that went public between 2001 and 2006 in the equity markets of the six Gulf Cooperation Council $(G C C)$ countries. The average initial abnormal returns of 290 percent exceed those found in the existing literature for both developed and emerging markets IPOs. Although the IPOs' returns over the one-year horizon beat the market index benchmark, they present negative abnormal returns once initial returns are excluded, which is consistent with findings in other industrial and emerging markets. The empirical models reject the hypothesis that the IPOs' performance is driven by the common independent variables employed in the literature. On the contrary, in the case of the GCC, country-and industry-specific characteristics, in addition to the timing of the offers, play key roles in explaining the abnormal returns of IPOs. This paper's empirical findings support the hypothesis that investors initially tend to be over-optimistic about the performance of IPOs, but grow more pessimistic over time.
\end{abstract}

JEL Classification Numbers: G12, G14

Keywords: IPO, underpricing, stock performance, GCC

Author’s E-Mail Address:abdullah.alhassan@gmail.com; fdelgado@imf.org; and mmomran@egyptse.com 


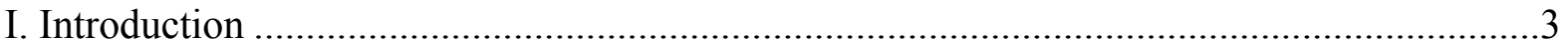

II. Institutional Settings and Latest Developments in the GCC Stock Markets.......................4

III. Data Selection and Sample Construction..................................................................

IV. Empirical Models, Methodology, and Key Descriptive Statistics..................................

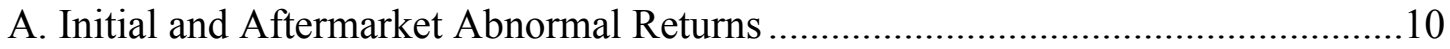

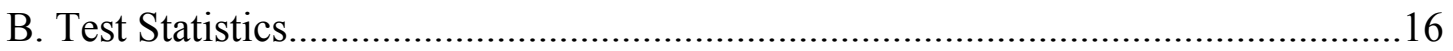

C. Determinants of Initial and Aftermarket Abnormal Returns ..............................16

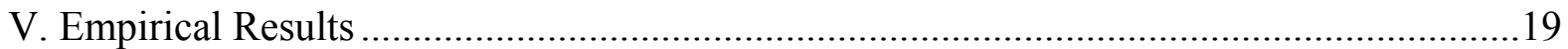

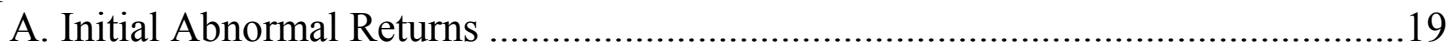

B. Aftermarket Abnormal Performance...............................................................22

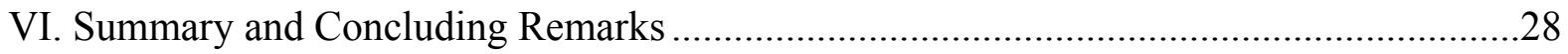

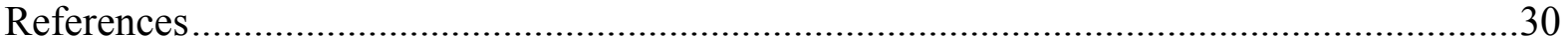

Appendix I: Detailed Information on the Performance of IPOs by Country ...........................33

Tables

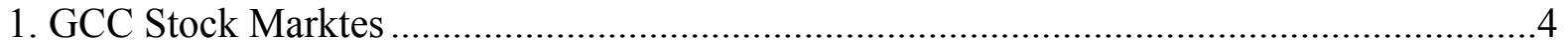

2. Equity Markets in Selected MENA Countries: Selected Indicators: $2000-05$...................5

3. Classification of IPOs in the GCC Countries from 2001-06...........................................

4. Basic Descriptive Statistics for Initial and Aftermarket Returns of IPOs .........................15

5. Initial Abnormal Returns of IPOs in the GCC ..........................................................20

6. Multivariate Cross-Sectional Regression Analysis for the Determinants of

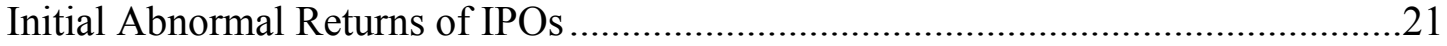

7. Aftermarket Abnormal Returns of IPOs in the GCC .....................................................23

8. Multivariate Cross-Sectional Regression Analysis for the Determinants of Aftermarket Abnormal Returns of IPOs ..............................................................2

Figures

1. Performance of GCC Stock Price Indices, 2003-05 ........................................................5

2. Performance of Stock Price Indices, January 2006-April 9, 2007 ................................6

3. Performance of GCC Stock Price Indices, 2003-February 2005 ...................................6

4. Total Number of IPOs in GCC Equity Markets................................................................ 


\section{INTRODUCTION}

1. This paper provides additional evidence on the short- and long-run performance of initial public offerings (IPOs) in the fast-growing emerging markets of the Gulf Cooperation Council (GCC). ${ }^{1}$ The first objective of this study is to analyze IPOs' performance in the short- and long-run against the benchmark of the equity markets' general price indices. The second objective is to find the main determinants of these IPOs' abnormal returns.

2. Most empirical studies show significant initial positive returns for IPOs. Loughran, Ritter, and Rydqvist update their information in a Pacific-Basin Finance Journal article (1994) in May 2006 and find that the average initial returns for 39 countries are as low as 5.4 percent for Canada and as high as 256.9 percent for China. ${ }^{2}$ Several other researchers document similar positive initial returns for IPOs. ${ }^{3}$

3. In contrast to the widespread findings of initial positive returns for IPOs, mixed results are found regarding their long-run performance, Although some empirical analysis find positive market-adjusted excess returns (or abnormal returns) in the long run, insignificant and/or negative abnormal returns for IPOs are found in most studies. ${ }^{4}$

4. Using a sample of 47 firms $^{5}$ that went public between 2001 and 2006, the results show that IPOs yield economically and statistically significant initial abnormal returns in line with the underpricing phenomenon of IPOs. ${ }^{6}$ The average initial abnormal returns of 290 percent exceed those found in the existing literature for both developed and emerging markets IPOs. Although the IPOs' returns over the one-year horizon beat the market index benchmark, they yield negative abnormal returns once initial returns are excluded, which is

\footnotetext{
${ }^{1}$ Bahrain, Kuwait, Oman, Qatar, Saudi Arabia, and the United Arab Emirates (U.A.E.).

${ }^{2}$ For a complete list of countries and the 2006 update of the table from Loughran and others (1994), see http://bear.cba.ufl.edu/ritter/publ_papers/Int.pdf

${ }^{3}$ See for example, Jenkinson and Mayer (1988) for the UK and France; Perotti and Guney (1993) for Malaysia, Spain, and Turkey; Dewenter and Malatesta (1997) for 8 countries; Choi and Nam (1998) for 30 countries; Paudyal, Saadouni, and Briston (1998) for Malaysia; Jelic and Briston (1999) for Hungary; Jones, Megginson, Nash, and Netter (1999) for 59 countries; and Aussenegg (2000) for Poland.

${ }^{4}$ Ritter (1991) documents negative long-run returns for 1,526 IPOs in the United States; Aggarwal, Leal and Hernandez (1993) for 9 Chilean firms; Keloharju (1993) for a sample of 79 Finnish IPOs; Leleux and Muzyka (1997) for 56 French IPOs; Aussenegg (2000) for 83 IPOs in Poland; Derrien and Womack (2003) for 264 IPOs in France; and Jaskiewicz, Gonzalez, Menendez, and Schiereck (2005) for 153 and 43 German and Spanish IPOs. For a complete list of the IPOs bibliography, visit the following website: http://www.iporesources.org//iporefs/

${ }^{5}$ Eighteen IPOs did not have at least one year of data after listing, thus reducing the number of observations for calculating long-run returns to 29.

${ }^{6}$ For the purpose of this paper, IPOs underpricing and performance correspond to the same economic concept, as underpricing is defined as the difference between the subscription price and the closing price of the first trading day (initial underpricing, leading to initial returns).
} 
consistent with findings in other mature and emerging markets. On average, the initial abnormal returns overcompensate for the negative returns over the one-year period, thus resulting in overall positive abnormal returns. Employing several multivariate regressions, the empirical models reject the hypothesis that common independent variables employed in the literature are relevant determinants of the GCC IPOs' abnormal returns. On the contrary, there is evidence that country- and industry-specific characteristics, in addition to the timing of the offers, play key roles in explaining IPO performance in the region. The empirical findings of this paper support the hypothesis that investors are initially over-optimistic about an IPO's performance, but grow more pessimistic over time.

5. The remainder of the paper is organized as follows: Section II provides a background of the institutional settings and latest developments in the GCC stock markets. Section III highlights data selection and sample construction. Section IV specifies the methodology for measuring initial and aftermarket abnormal returns of IPOs, the statistical techniques used to investigate the behavior of IPOs, the factors that drive IPOs' performance, and presents several key descriptive statistics. The empirical findings are presented and discussed in Section V. Section VI contains the summary and concluding remarks.

\section{InStitutional Settings AND LATEST DeVelopMents In THE GCC STOCK MARKETS}

\begin{tabular}{|llc|}
\hline \multicolumn{3}{|c|}{ Table 1. GCC Stock Markets } \\
Country & Market & Year of Establishment \\
\hline Bahrain & Bahrain Stock Exchange (BSE) & 1987 \\
Kuwait & Kuwait Stock Exchange (KSE) & 1977 \\
Oman & Muscat Securities Market (MSM) & 1988 \\
Qatar & Doha Securities Market (DSM) & 1995 1/ \\
Saudi Arabia & Tadawul & 1984 2/ \\
U.A.E. & Abu Dhabi Security Market (ADSM) & 2000 \\
U.A.E. & Dubai Financial Market (DFM) & 2000 \\
\hline Sources: BSE; KSE; MSM; DSM; Tadawul; ADSM; and DFM. \\
\hline 1/ Activities started in May 1997. \\
2/ Although the Tadawul platform was launched in October 2001, an organized stock market \\
has existed since 1984.
\end{tabular}

6. Since their inception over the past two decades, GCC equity markets have generally underperformed vis-à-vis the equity markets in industrial countries and some large emerging markets. Except for short-lived and isolated speculative outbursts, their growth and profitability have been well below major equity markets in industrial countries and only marginally above the Morgan Stanley Emerging Markets Index (MSCI). These boom-and- 
bust episodes included the 1982 Al-Mannak bubble in Kuwait, mainly due to the lack of effective regulation for over-the-counter trade; the 1991 Saudi Arabian bubble, prompted by the repatriation of funds after the Kuwaiti invasion; and the 1997 Omani bubble after the stock exchange's opening to foreign investors.

\begin{tabular}{|c|c|c|c|c|c|c|c|c|}
\hline \multirow[t]{2}{*}{ Market } & \multicolumn{2}{|c|}{$\begin{array}{c}\text { Market } \\
\text { capitalization } \\
\text { (in billion US\$) }\end{array}$} & \multicolumn{2}{|c|}{$\begin{array}{l}\text { Market cap. } \\
\text { (in percent of } \\
\text { GDP) }\end{array}$} & \multicolumn{2}{|c|}{$\begin{array}{l}\text { Value traded } \\
\text { (in billion US\$) }\end{array}$} & \multicolumn{2}{|c|}{$\begin{array}{l}\text { Turnover ratio } \\
\text { (in percent) }\end{array}$} \\
\hline & 2000 & 2005 & 2000 & 2005 & 2000 & 2005 & 2000 & 2005 \\
\hline Egypt & 28.5 & 79.5 & 30.7 & 72.4 & 11.8 & 27.7 & 34.7 & 34.8 \\
\hline Jordan & 4.9 & 37.6 & 58.5 & 289.1 & 0.4 & 23.8 & 7.7 & 63.3 \\
\hline Kuwait & 19.8 & 141.5 & 56.1 & 190.0 & 4.4 & 97.3 & 22.2 & 78.5 \\
\hline Qatar & 8.2 & 87.1 & 46.2 & 253.6 & 0.4 & 28.3 & 4.5 & 32.4 \\
\hline Saudi Arabia & 67.9 & 646.0 & 36.0 & 210.0 & 17.4 & $1,103.7$ & 25.6 & 170.8 \\
\hline U.A.E. & 11.0 & 231.4 & 15.7 & 178.5 & 0.1 & 140.6 & 1.0 & 60.8 \\
\hline GCC & 117.0 & $1,135.5$ & 34.2 & 191.6 & 23.03 & $1,373.9$ & 19.7 & 121.0 \\
\hline MENA & 312.0 & $1,594.6$ & 33.0 & 106.2 & 232.0 & $1,675.0$ & 75.0 & 106.0 \\
\hline
\end{tabular}

7. In early 2003, propelled by increasing oil prices, record corporate profits, and sustained structural reforms, stock prices in most GCC markets ${ }^{7}$ began to increase rapidly. Excluding Oman and Bahrain, whose markets kept to a moderate growth path, the GCC weighted price index ${ }^{8}$ increased by 480 percent on average in the three-year period 2003-05. By any standard, this was an outstanding performance. The

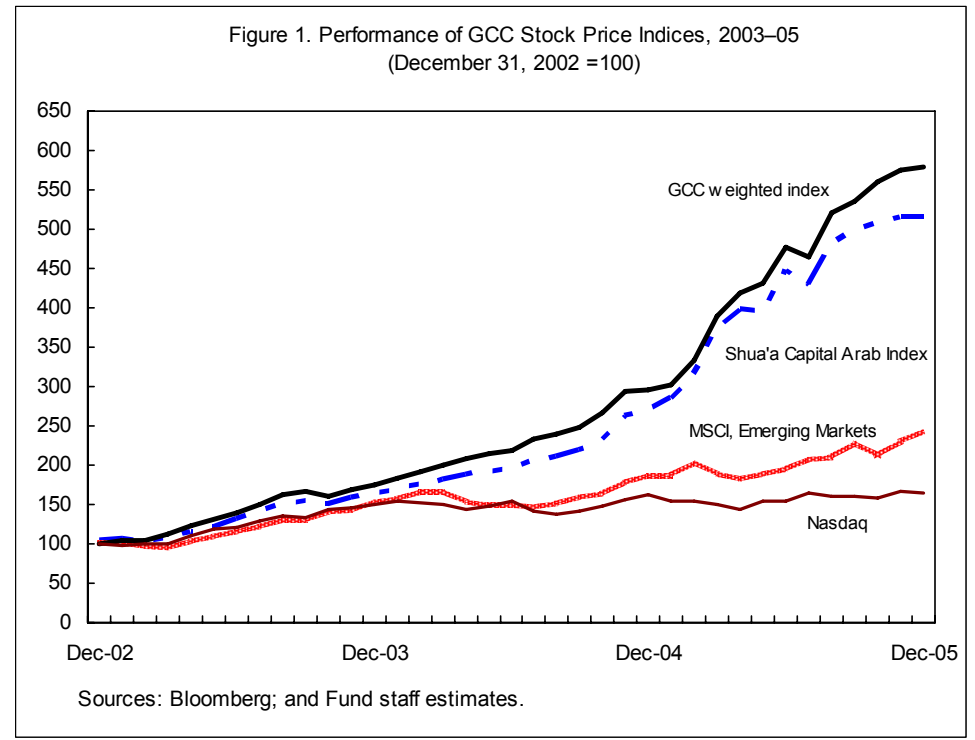

\footnotetext{
${ }^{7}$ There are seven equity markets in the GCC countries: the Bahrain Stock Exchange (BSE), the Kuwait Stock Exchange (KSE), the Muscat Securities Market (MSM), the Doha Securities Market (DSM), the Saudi Stock Market (Tadawul), the Abu-Dhabi Securities Market (ADSM), and the Dubai Financial Market (DFM).

${ }^{8}$ The index includes the seven regional markets using market capitalization (in U.S. dollars at end-2003 exchange rates) as weight. The resulting weights are 51.6 percent for Saudi Arabia; 22.2 percent for Kuwait; 14.4 percent for the U.A.E.; 6.5 percent for Qatar; 3.5 percent for Oman; and 1.8 percent for Bahrain.
} 
GCC outperformed the MSCI, which grew by 140 percent during the same period, and only other Middle East markets with some similar characteristics, such as Egypt and Jordan, were able to outperform the GCC markets. The size and depth of the GCC markets increased dramatically during the same period, well beyond other Middle East and North Africa (MENA) markets and the average in emerging markets and industrial countries. Total GCC market capitalization jumped from $\$ 117$ billion (38 percent of the entire MENA region in 2000 ) to $\$ 1.1$ trillion (71 percent of the MENA region in 2005).

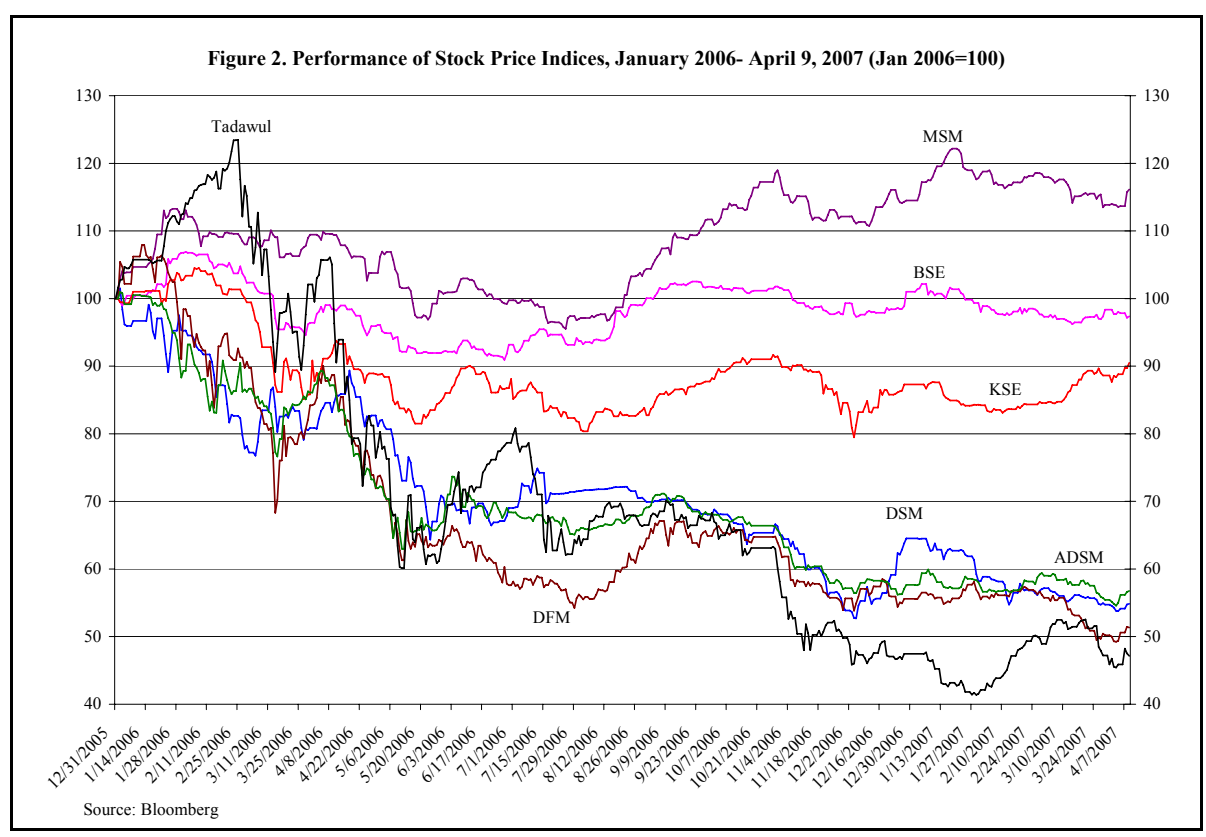

8. Market sentiment, however, began to change in late 2005, and a sharp correction swept most markets in early 2006. The spreading gap between the increase in stock prices and economic fundamentals and the growing perception of overvaluation resulted in a price correction in the region's major markets (Saudi Arabia, U.A.E., Qatar, and, to a lesser extent, Kuwait). The triggers for the correction were related to marketspecific factors and explain why prices started to decline on different dates, beginning with the Qatari market in September 2005.

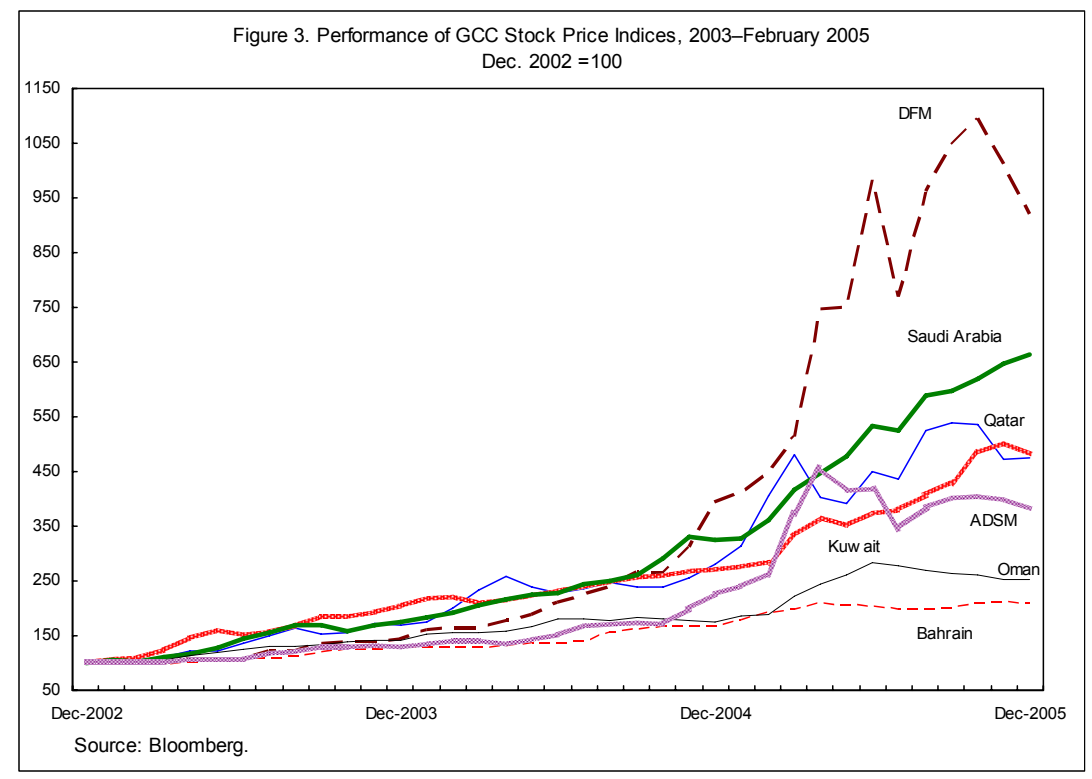


Driven mainly by the bullish Saudi market, the GCC weighted price index continued to increase until February 2006, when it reached its peak of over 530 percent above the end2002 level. The correction was across the board and accelerated sharply in the following three-month period through end-May 2006, with the cumulative losses amounting to 4060 percent from the peak values of the stock price indices. ${ }^{9}$ As of end-2006, price volatility remained high in most markets, and upward movements had been short-lived despite the substantial improvement in the valuation ratios of most blue chip stocks.

9. The substantial increase in the number of IPOs in 2005 in some GCC equity markets was one of the warning signals that confirmed the development of a speculative bubble. According to Morck, Shleifer, and Vishny (1990), companies tend to issue equity when equity is overpriced, while debt issues or internal financing are preferred when equity is not overpriced. Accordingly, overheated markets are usually associated with abnormally intense IPO activity. Also, bullish markets' investor euphoria frequently results in companies without a track record being able to raise substantial capital through IPOs, which increases the risk of losses, particularly for small, ill-informed investors. This phenomenon, however, was

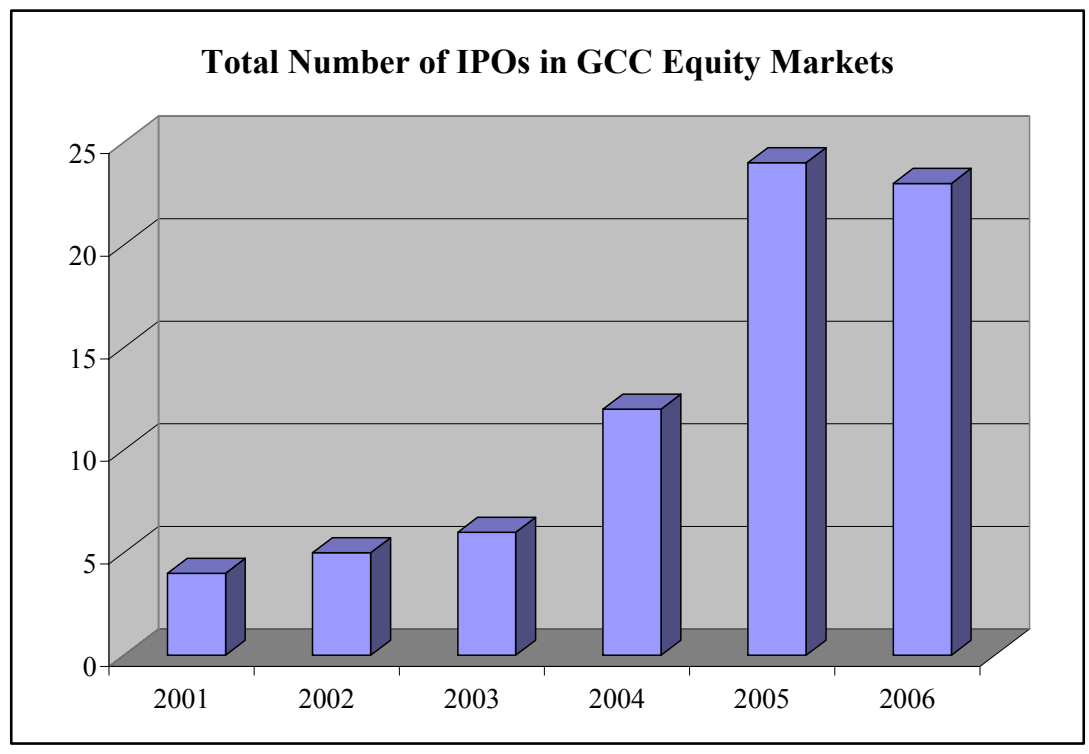
only partially present in some booming GCC markets, and it accelerated towards the peak of the markets in the turn of the year 2005. Thus, the number of IPOs in 2005 and 2006 was very similar (24 against 23 , respectively), although the inertia of the booming period was evident in the $1 / 3$ increase of capital subscribed in 2006 , from $\$ 5.6$ billion to $\$ 7.5$ billion. The following section provides further breakdown of these IPOs and details the composition of the sample used in this paper.

\section{Data Selection And SAMple Construction}

10. The data set analyzed includes GCC firms that went public from 2001 to 2006 and were listed for trading in the stock exchanges as of June 2006.

\footnotetext{
${ }^{9}$ There was no correction in the MSM and BSE, although prices fell slightly in the first half of 2006. The KSE was less affected by the correction, with the general price index falling by 22.5 percent from its peak value to its lowest point on August 2, 2006.
} 
8

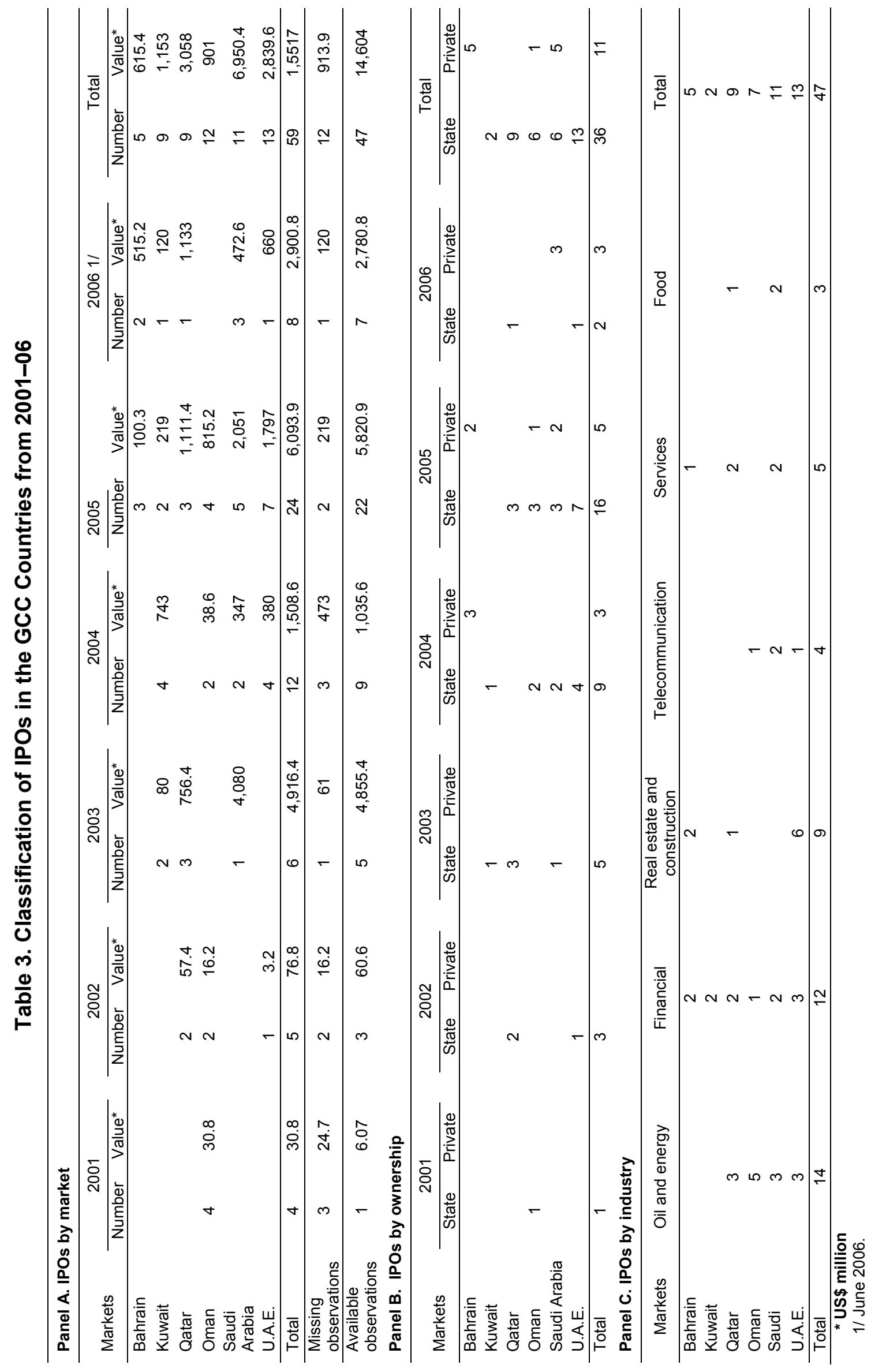


11. There were 59 IPOs in the GCC countries from 2000 until June 2006, with a total value of $\$ 15.5$ billion (Table 3, Panel A). After excluding the IPOs that are not tradable yet in the stock market, and those presenting data limitations, the number of useful observations was reduced to 47. Most of these 47 IPOs come from the booming stock markets of the U.A.E., Saudi Arabia, and Qatar. Also, the highest number and value of IPOs took place during the peak of the bull market in the region in 2005. More than 75 percent of the sample firms were either state-owned or the state intervened in the IPO process by determining the share prices because they operate in regulated industries and they are subject to licensing to start operations (Table 3, Panel B). ${ }^{10}$ In terms of industry, most firms issuing IPOs operate in the oil and energy industry, financial sector (mainly banks), and real estate and construction (Table 3, Panel C). This is consistent with the ongoing expansion and diversification of the region's economy as the three economic sectors mentioned above are among the fastest growing ones in the GCC countries.

12. The sources to build the database of this study include ABQ Zawya and Gulf Base for the IPO prospects as they provide comprehensive information on the date, the price and the size of the issue; percentages of equity sold; and the size of the oversubscription. Shuaa Capital Limited's database was used to gather data on relevant corporate actions such as stock splits, dividend payments, capital increases, and stock bonuses to calculate the effective returns of IPOs. Finally, the stock exchanges of each of the GCC countries provided the daily data on stock prices and general indices used as benchmarks.

\section{Empirical Models, Methodology, And Key Descriptive Statistics}

13. The initial and aftermarket abnormal returns are calculated using the general market index of each corresponding country as a benchmark. The parametric test statistic and the non-parametric Wilcoxon signed-rank test are used to examine whether IPOs obtain abnormal returns in the short and long run. Also, the Mann-Whitney test is used to compare the relevance of differences in medians between two samples after splitting the sample by country, year, percentage of oversubscription, industry, and initial abnormal returns. Additionally, multivariate models are constructed to test the relevance of a number of predetermined drivers in explaining IPO performance.

\footnotetext{
${ }^{10}$ Those are telecommunications, financial, and oil and energy-related firms.
} 


\section{A. Initial and Aftermarket Abnormal Returns}

\section{Initial Abnormal Returns}

14. Each IPO's initial return is calculated by taking the difference between the offering price and the closing price of the first trading day as follows:

$$
r_{i}=\frac{P_{i, t}-P_{i, 0}}{P_{i, 0}}
$$

where $r_{i}$ is the gross initial return for security $i$ from the subscription period to the closing of the first trading day, $P_{i, t}$ is the closing price of security $i$ at the first trading day, and $P_{i, 0}$ is the offer price of security $i$ at the time of subscription. ${ }^{11}$

15. However, the above equation does not properly measure the relevant (net) raw initial return for investors, as many other factors could affect such a return: ${ }^{12}$

- $\quad$ In some cases, investors can not get the amount of shares they apply for as demand for shares exceeds the available supply, resulting in a rationing of shares. In these situations, investors bear extra costs for the amount of capital tied up in the subscription but not given an allocation;

- $\quad$ Also, there may exist IPO-specific transaction costs, including brokerage commissions and other fixed costs. These costs vary widely depending on firm, sector, country, and market conditions, among others. Thus, a case by case adjustment was made to calculate accurately the net raw initial returns of each IPO.

16. The following equation was used to calculate the net raw initial returns for each IPO:

$r_{i}=\frac{P_{i, t}-P_{i, 0}}{P_{i, 0}}-\left[\frac{A R F_{0, t}(S D-T D)}{365} \times(1-\Psi)+\frac{T C_{i}}{P_{i, 0}}\right]$

where $A R F_{0, t}$ represents the average risk-free rate from the date of subscription to the date of trading, ${ }^{13} S D-T D$ is the number of days elapsed between the last day of subscription and

\footnotetext{
${ }^{11}$ All share prices series were homogenized taking into account nominal splits, dividends paid and other corporate actions affecting the value of the share and the return for the investor.

${ }^{12}$ See Keloharju, 1993; Menyah and others, 1995; and Omran, 2005.

${ }^{13} A R F$ is proxied by the one-month bank customer deposit rates, as reported in line 60k in the IMF's International Financial Statistics (IFS) for all countries, except for Qatar where the interest rate was obtained from Qatar Central Bank's website.
} 
the first day of trading. $\Psi$ is the percentage of shares allocated, and $T C_{i}$ is the transaction cost for each security of firm $i$.

17. The abnormal return is calculated as the return on an IPO minus the benchmark return for the corresponding reference portfolio, in this case the country general price index. ${ }^{14}$

$a r_{i}=r_{i}-r_{\text {crp }}$

where $a r_{i}$ is the initial abnormal return for security $i$ and $r_{c r p}$ is the return on the general equity market index from the IPO subscription period to the closing of its first trading day, and is calculated as follows:

$r_{c r p}=\frac{I_{i, t}-I_{i, 0}}{I_{i, 0}}$

where $I_{i, t}$ refers to the price index of the corresponding reference portfolio $i$ (the general market index of a given GCC country, in which the IPO is listed) at the end of the first trading day of security $i$, and, $I_{i, 0}$ is the price index of the corresponding reference portfolio $i$ at the last day of subscription of security $i$.

\section{Aftermarket Abnormal Returns}

18. There are several methodologies that could be used to calculate the aftermarket performance of IPOs, and there is no consensus on which of them yields better results. ${ }^{15}$ Therefore, two main methods are used to calculate the aftermarket performance of GCC IPOs: the cumulative abnormal returns (CAR) ${ }^{16}$ and the buy-and-hold abnormal returns (BHAR). ${ }^{17}$ Also, the wealth relative index (WR), and the Sharp-Lintner's capital asset pricing model (CAPM) are applied to each of the two main methods.

19. Given the data limitations and the fact that most IPOs in the sample have taken place recently, the aftermarket performance period is defined as the return obtained by investors

\footnotetext{
${ }^{14}$ Although the use of more appropriate benchmarks such as the control firm approach would have been preferred because of the obstacles of the new listing bias, the rebalancing bias, and the skewness problem (Barber and Lyon, 1997), the number of listed firms in each of the GCC markets is too small to allow the use of such methodology.

${ }^{15}$ See among others, Barber and Lyon, 1997; Kothari and Warner, 1997; Brav and Gompers, 1997; and Lyon, Barber, and Tsai, 1999.

${ }^{16} \mathrm{CAR}$ could be defined as the difference between the cumulative return obtained by investors acquiring a particular IPO (i) against the cumulative return of the corresponding reference portfolio (crp) during the same period of time (t): $C A R_{i, t}=C R_{i, t}-C R_{c r p, t}$

${ }^{17}$ See definition in (9), paragraph 24.
} 
buying on the first day of listing after one year of the IPO listing date, exclusive of initial returns. Since the initial return period is denoted by month 0 , the after-market period includes 12 months, where months are defined as 21 successive trading-day periods relative to the IPO listing date. Thus, the first month of an IPO aftermarket performance incorporates listing days 2-22; the second month incorporates listing days 23-43, and so on. Each individual IPO is controlled over the period of calculation in order to truncate the aftermarket period if any firm is delisted before its anniversary. ${ }^{18}$

20. Monthly abnormal returns are defined as the monthly return on a security $i$ minus the monthly corresponding reference portfolio return for the same 21-trading-day period:

$$
A R_{i, t}=R_{i, t}-R_{c r p, t},
$$

where $A R_{i, t}$ is the abnormal return for security $i$ for the after-market month $t, R_{i, t}$ refers to the raw return for security $i$ for the after-market month $t$, and $R_{c r p, t}$ is the raw return on the corresponding reference portfolio for the after-market month $t$.

21. Therefore, the CAR for each individual IPO is:

$$
C A R_{i, s, e}=\sum_{i=s}^{e} A R_{i, t}
$$

where $C A R_{i, s, e}$ is the cumulative abnormal return for security $i$ from month $s$ to month $e$, where $s$ is the starting month after the IPO listing and $e$ is the anniversary month of the IPO listing date (12 months) or until the date of delisting due to mergers, acquisitions, takeovers, bankruptcies, non-trading, or other reasons.

22. The average abnormal return on a portfolio of $n$ securities for month $t$ is defined as the equally weighted arithmetic average of the abnormal returns as follows:

$$
\operatorname{Avg} A R_{t}=\frac{1}{n_{t}} \sum_{i=1}^{n_{t}} A R_{i, t}
$$

where $A v g A R_{t}$ is the average abnormal return on a portfolio of IPOs for month $t$, and $n_{t}$ is the number of securities of IPOs listed during month $t$.

23. Thus, the cumulative abnormal return on a portfolio of $n$ securities is calculated as follows:

$$
C A R_{s, e}=\sum_{t=s}^{e} A v g A R_{t}
$$

\footnotetext{
${ }^{18}$ For the entire sample, no firm was delisted over the period of the study.
} 
where $C A R_{s, e}$ is the cumulative abnormal return on a portfolio of IPOs from month $s$ to month $e$.

24. However, CAR methods implicitly assume monthly portfolio rebalancing, which may or may not be a realistic assumption of the trading strategy of the average GCC IPO investor. Alternatively, the BHAR method calculates after-market performance over the long-run (one-year period) for each individual IPO and its corresponding reference portfolio without any portfolio rebalancing. According to the BHAR method, the abnormal return of an IPO over a one-year period could be calculated as follows:

$B H A R_{i, T}=B H R_{i, T}-B H R_{c r p, T} ;$ or:

$B H A R_{i, T}=\left[\prod_{t=1}^{\min \{T, \text { delisting }\}}\left(1+r_{i, t}\right)-1\right]-\left[\prod_{t=1}^{\min \{T, \text { delisting }\}}\left(1+r_{c r p, t}\right)-1\right] \quad T=252$,

where $B H A R_{i, T}$ is the buy-and-hold abnormal return for security $i$, in period $T$, where $\mathrm{T}$ is aftermarket trading day number 252, $t=1$ indicates the first aftermarket trading day (listing date), and $\min \{T$, delisting $\}$ refers to the last day before delisting an IPO.

25. Since BHAR is calculated for each individual IPO, the average BHAR for a sample of $n$ IPOs is given by:

$$
A v g B H A R_{T}=\frac{1}{n_{t}} \sum_{i=1}^{n_{t}} B H A R_{i, T} \quad T=252,
$$

where $A v g B H A R_{T}$ is the average BHAR over the period $T$, and $n_{t}$ is the number of IPOs considered during the period (252 days).

26. Ritter (1991) and others introduced the WR index to compare the average buy-andhold return of an IPO portfolio relative to its corresponding reference portfolio. A WR index greater than 1.00 means that IPOs outperform their corresponding reference portfolio and vice-versa. The WR index is calculated as follows:

$$
W R_{T}=\frac{1+A v g B H R_{T, I P O S}}{1+A v g B H R_{T, c r p}} \quad T=252,
$$

where $W R_{T}$ is the wealth relative index over period $T, A v g B H R_{T, I P O S}$ is the buy-and-hold return for a portfolio of IPOs over period $T$, and $A v g B H R_{T, c r p}$ is the buy-and-hold return for the corresponding reference portfolio over period $T$.

27. None of the models mentioned above are adjusted for the specific risk of the IPO stocks. Sharp-Lintner's CAPM is used to calculate the aftermarket abnormal returns taking into account the risk of each individual IPO, as follows: 
$\operatorname{CAPMAR}_{i, t}=R_{i, t}-R_{f, t}-\beta_{i}\left[R_{c r p, t}-R_{f, t}\right]$

where $C A P M A R_{i, t}$ is the risk-adjusted abnormal return for firm $i$ in month $t, R_{f, t}$ is the riskfree rate proxied as a short-term one-month bank deposit rate, $\beta_{i}$ is the risk of security $i$ compared with the corresponding reference portfolio and is obtained from the CAPM regression. ${ }^{19}$ The risk-adjusted return rates are used to calculate the aftermarket abnormal return of IPOs following the two methods (CARs and BHARs) described above.

\section{Summary of Results}

28. On average, IPOs yield around 315 percent on the first trading day (Table 4, Panel A). This is far above the average returns on the corresponding reference portfolios and exceeds what is documented for any developed or emerging economies. Some investors obtained initial returns as high as 1,430 percent and others achieved negative initial returns as low as 30 percent (Appendix I). Also, IPOs seem to perform better than the market over the initial one-year period, regardless of methods or models of calculations (Table 4, Panel B). However, excluding initial returns, IPOs tend to perform far below their benchmarks (Table 4, Panel C). This means that most of the total abnormal after-market returns of IPOs in the GCC were due to the underpricing of the issues and, thus, on average, investors who bought IPOs on the first trading day achieved lower returns relative to the market. ${ }^{20}$

\footnotetext{
${ }^{19}$ Slope from regressing $\left[R_{i, t}-R_{f, t}\right]$ on $\left[R_{c r p, t}-R_{f, t}\right]$ for the estimation period.

${ }^{20}$ Detailed performance of each IPO classified by country is presented in the Appendix.
} 
Table 4. Basic Descriptive Statistics for Initial and Aftermarket Returns of IPOs

\begin{tabular}{|c|c|c|c|c|c|c|}
\hline \multicolumn{7}{|c|}{ Panel A: Initial returns (47 firms) } \\
\hline & \multicolumn{3}{|c|}{ IPO returns (ar) } & \multicolumn{3}{|c|}{ Market returns (crp) } \\
\hline Mean & \multicolumn{3}{|c|}{3.15} & \multicolumn{3}{|c|}{0.25} \\
\hline Median & \multicolumn{3}{|c|}{1.52} & \multicolumn{3}{|c|}{0.07} \\
\hline Maximum & \multicolumn{3}{|c|}{14.3} & \multicolumn{3}{|c|}{2.09} \\
\hline Minimum & \multicolumn{3}{|c|}{-0.3} & \multicolumn{3}{|c|}{-0.3} \\
\hline Standard deviation & \multicolumn{3}{|c|}{3.45} & \multicolumn{3}{|c|}{0.53} \\
\hline Standard skewness & \multicolumn{3}{|c|}{4.6} & \multicolumn{3}{|c|}{6.47} \\
\hline Standard kurtosis & \multicolumn{3}{|c|}{3.48} & \multicolumn{3}{|c|}{7.43} \\
\hline \multicolumn{7}{|c|}{ Panel B: 12-month cumulative returns and buy-and-hold returns including initial returns (29 firms) } \\
\hline & \multicolumn{3}{|c|}{ Cumulative returns $(\mathrm{CR})$} & \multicolumn{3}{|c|}{ Buy-and-hold returns (BHR) } \\
\hline & IPOs & Market & CAPM & IPOs & Market & CAPM \\
\hline Mean & 3.9 & 1.13 & 0.80 & 3.90 & 1.1 & 0.72 \\
\hline Median & 3.0 & 1.12 & 0.72 & 2.50 & 0.77 & 0.53 \\
\hline Maximum & 14.40 & 4.65 & 2.70 & 14.62 & 7.45 & 4.30 \\
\hline Minimum & 0.25 & -0.59 & -0.65 & -0.01 & -0.20 & -0.22 \\
\hline Standard deviation & 3.53 & 1.23 & 0.80 & 3.70 & 1.50 & 0.90 \\
\hline Standard skewness & 3.40 & 2.52 & 0.60 & 3.34 & 7.04 & 5.33 \\
\hline Standard kurtosis & 2.60 & 2.85 & -0.16 & 2.24 & 13.90 & 9.4 \\
\hline \multicolumn{7}{|c|}{ Panel C: 12-month cumulative returns and buy-and-hold returns excluding initial returns (29 firms) } \\
\hline & \multicolumn{3}{|c|}{ Cumulative returns $(\mathrm{CR})$} & \multicolumn{3}{|c|}{ Buy-and-hold returns (BHR) } \\
\hline & IPOs & Market & CAPM & IPOs & Market & CAPM \\
\hline Mean & 0.20 & 0.71 & 0.46 & 0.23 & 0.46 & 0.31 \\
\hline Median & 0.27 & 0.94 & 0.40 & 0.19 & 0.51 & 0.24 \\
\hline Maximum & 1.32 & 3.09 & 1.80 & 2.04 & 2.30 & 1.33 \\
\hline Minimum & -1.0 & -0.96 & -0.98 & -0.71 & -0.46 & 0.45 \\
\hline Standard deviation & 0.58 & 0.98 & 0.79 & 0.67 & 0.64 & 0.50 \\
\hline Standard skewness & -0.41 & 0.17 & -0.26 & 2.20 & 1.63 & 0.85 \\
\hline Standard kurtosis & -0.22 & -0.13 & -0.86 & 1.25 & .98 & -0.82 \\
\hline
\end{tabular}

29. Standardized skewness and kurtosis tests are used to determine whether the variables measuring IPOs' returns can be adequately modeled by a normal distribution. Values of these statistical tests outside the range of -2 to +2 indicate significant departures from normality, which would tend to invalidate many of the statistical procedures usually applied to this data. Since the results show that the values of the standardized skewness and kurtosis for some return measures are outside the range, these variables are not normally distributed..$^{21}$ As a result, the parametric test for the significant difference in mean should be interpreted with caution.

\footnotetext{
${ }^{21}$ A chi-square test was run for robustness, and a Shapiro-Walks W test for normality. Both results yielded similar results.
} 


\section{B. Test Statistics}

30. The null hypothesis that the cross-sectional average initial and aftermarket abnormal returns are equal to zero for a sample of $n$ IPOs is tested using the following parametric tests:

$$
\begin{aligned}
& \operatorname{tar}=\overline{\operatorname{ar}} /(\sigma a r / \sqrt{n}) \\
& t C A R=\overline{C A R_{s, e}} /\left(\sigma C A R_{s, e} / \sqrt{n}\right) \\
& t B H A R=\overline{B_{H A R_{T}}} /\left(\sigma B H A R_{T} / \sqrt{n}\right) \\
& t C A P M A R=\overline{C A P M A R_{s, e}} /\left(\sigma C A P M A R_{s, e} / \sqrt{n}\right) \\
& t B H C A P M A R=\overline{B H C A P M A R_{T}} /\left(\sigma B H C A P M A R_{T} / \sqrt{n}\right) \\
& \text { where } \overline{a r}, \overline{C A R_{s, e}}, \overline{B H A R_{T}}, \overline{C A P M A R_{s, e}}, \text { and } \overline{B H C A P M A R_{T}} \text { are the sample averages of } \\
& \text { initial abnormal returns, and aftermarket } \mathrm{CAR} \text { and } \mathrm{BHAR}, \mathrm{using} \text { risk unadjusted and adjusted } \\
& (\mathrm{CAPM}) \text { methods, respectively, and } \sigma a r, \sigma C A R_{s, e}, \sigma B H A R_{T}, \sigma C A P M A R_{s, e} \text { and } \\
& \sigma B H C A P M A R_{T} \text { are the cross-sectional sample standard deviations of initial abnormal } \\
& \text { returns, and aftermarket CAR and BHAR using risk unadjusted and adjusted (CAPM) } \\
& \text { methods, respectively. }
\end{aligned}
$$

31. Under the null hypothesis, these test statistics follow a Student's $t$-distribution if the sample is normally distributed. Given the fact that some return measures seem to be positively skewed, an alternative non-parametric, Wilcoxon signed-rank test statistic is used to test the null hypothesis that the median of abnormal returns is equal to zero. The MannWhitney test for difference in medians is used to compare each pair of IPOs' sub-samples. Even though the non-parametric test statistic is less sensitive to the presence of outliers, it is, nonetheless, less powerful than the $t$-test if the data are normally distributed. Hence, both test statistics are used for the robustness of the results, but the findings from the parametric $t$-test should be treated with caution if their corresponding return measures are not normally distributed.

\section{Determinants of Initial and Aftermarket Abnormal Returns}

32. The determinants of the initial and aftermarket abnormal IPO returns are analyzed by estimating several cross-sectional regressions based on a number of predetermined exogenous variables. A list of independent variables that are used as determinants of IPOs' abnormal results in the literature, along with the expected positive or negative relationships are described below.

\section{Initial Abnormal Returns}

33. Ex-ante uncertainty (positive): One possible explanation for the underpricing of IPOs is that issuers anticipate investors" "ex-ante uncertainty" regarding the future performance of IPOs. Thus, underpricing might be required to convince uninformed investors to buy. The 
greater the ex-ante uncertainty, the greater the underpricing needed to attract investors. Ritter (1984) and Beatty and Ritter (1986) find a positive relationship between the level of underpricing and the non-observable ex-ante uncertainty. Following Ritter (1984), ex-ante uncertainty is measured by the standard deviation of daily returns of each individual IPO twenty-five days following its official listing.

34. Oversubscription (positive): IPOs' underpricing could also be related to the percentage of shares allocated, also known as "oversubscription." Some empirical studies have found a positive relationship between oversubscription and the level of underpricing. This has been analyzed, among others, by Rock (1986) in his model "winner's curse," and Paudyal and others (1998) from the point of view of the absorption capacity of the market. Oversubscription is measured by the multiple of IPO shares' demand on supply.

35. Proportion of shares offered (negative): Allen and Faulhaber (1989), Grinblatt and Hwang (1989), and Welch (1989) provide an alternative explanation for the underpricing of IPOs known as "signaling approach." They argue that firms sometimes phase their access to the market in two stages. During the first stage, the company offers a relatively small part of the capital it intends to sell to investors at a substantially discounted price. This is intended to foster a positive opinion among investors regarding the possibility of obtaining substantial initial returns from this company's IPOs. After this "signaling" is accomplished, it is expected that the firm could reach its capital placement targets at better prices. Also, Perotti (1995) argues that a similar strategy applies to government privatizations. Therefore, a negative relationship between the proportion of shares offered and the level of underpricing could be expected. The proportion of shares offered is measured as the percentage of shares offered through the IPO over the total shares of the company.

36. Market volatility (positive): The degree of underpricing may also depend on market volatility. Issuers may try to minimize the probability of unsuccessful issues by lowering prices as long as market volatility is high. In turn, a positive relationship between market volatility and the level of underpricing is expected. Menyah and others (1995) and Paudyal and others (1998) find this relationship in the United Kingdom and Malaysia, respectively. According to the same authors, the standard deviation of daily market returns over the twomonth period prior to the closing of the IPO subscription period is used for measuring market volatility.

37. Market sentiment (positive): The relationship between successful IPOs and bull markets is well documented in the literature. By timing their offerings when market liquidity is high, issuers and underwriters are usually able to achieve a smooth distribution of shares and to raise large amounts of capital. Derrien and Womack (2003) suggest that market sentiment plays an important role in determining the level of IPO underpricing. Indeed, in bullish markets, investors may be overly optimistic about a firm's prospects, causing the aftermarket equilibrium price to be greater than in normal conditions, thus increasing the initial abnormal returns of the IPOs and their implicit underpricing. In fact, in a bull market 
the level of underpricing of IPOs may be far higher than in a bear market. How, Izan, and Monroe (1995) analyze the Australian IPO market and confirm that the level of underpricing is high during bull periods and low during bear periods. Thus, a positive relationship between bull year issues (timing and markets) and initial abnormal returns is expected. Market sentiment is controlled by two dummy variables. Timing, controls for the year of issuance of the IPO and Country, controls for the stock market sentiment in the GCC countries. The "bullish" market extended during 2003-05, while the remainder of the period was "bearish." Also, Qatar, Saudi Arabia, and the U.A.E. could be classified as "bull” markets. Bahrain, Oman, and, to lesser extent, Kuwait, while not being strictly "bear" markets during this period, were less bullish than the rest of the regional markets. ${ }^{22}$

38. Type of industry: Some GCC countries (particularly the U.A.E., Saudi Arabia and Qatar) have implicit or explicit policies requiring that the offering prices of public companies being privatized and newly licensed companies in regulated sectors be related to the nominal value of the shares and not to their economic value, as a means to distribute wealth among the population at large. This factor alone could explain up to two-thirds of the Qatari stock price index gains during 2003-05, and up to one-third of the gains of Tadawul and ADSM during the same period. Therefore, IPOs in regulated industries would tend to have higher initial abnormal returns than those corresponding to non-regulated industries. Accordingly, a positive sign is expected for firms operating in regulated industries. This factor is controlled by introducing a dummy variable for firms operating in regulated industries.

39. The quantitative relationship between these variables and the initial abnormal IPO returns are analyzed by estimating equation (18):

$a r_{i}=\alpha+\beta_{1} E X A N T E_{i}+\beta_{2} O V R S_{i}+\beta_{3} P S O_{i}+\beta_{4} M V_{i}+\beta_{5} T I M_{i}+\beta_{6} C O N T_{i}+\beta_{7} I N D_{i}+\varepsilon_{i}$

where $a r_{i}$ is the abnormal initial return of firm $i$ that refers to the level of underpricing; $E X A N T E_{i}$ refers to the ex-ante uncertainty measured by the standard deviation of daily returns of firm $i$ twenty-five days following its official listing; $O V R S_{i}$ is the oversubscription level for shares of firm $i ; P S O_{i}$ is the proportion of shares offered of firm $i$; $M V_{i}$ measures market volatility; TIM $_{i}$ is a proxy for the time of IPOs, which equals one if firm $i$ went public in a booming year (market is bullish) and zero otherwise (market is bearish); $C O N T_{i}$ is a dummy variable that takes the form of one if firm $i$ is affiliated to the booming markets (Qatar, Saudi Arabia, and U.A.E.) and zero otherwise (Bahrain, Kuwait and Oman); and $I N D_{i}$ is a dummy variable that equals one if firm $i$ is classified as regulated industry and zero otherwise (non-regulated industry).

\footnotetext{
${ }^{22}$ The term "non-booming" is used for these markets in this paper.
} 


\section{Aftermarket (Long-Run) Abnormal Returns}

40. A cross-sectional regression is estimated to identify the significance of the predetermined exogenous variables in explaining the aftermarket abnormal returns of IPOs. The independent variables in the regression equations are similar to those explained in initial abnormal returns, except for three relevant aspects: (i) the relationship between oversubscription and long-run abnormal returns is expected to be negative, not positive as in the case of initial abnormal returns, because investors realize, in the long run, that they have been over-optimistic and the higher the over-optimism (oversubscription), the more likely that aftermarket abnormal performance is negative; (ii) the sign for the country and industry dummy variables included in the initial abnormal returns model is expected to reverse as investors' sentiment changes as markets cool down and actual profitability of firms in regulated industries is revealed; ${ }^{23}$ and (iii) an inverse relationship between initial abnormal returns and long-run performance is expected. This has been confirmed by empirical studies in a number of countries. ${ }^{24}$

41. Taking these considerations into account, equation (19) is used to estimate the explanatory power of the model:

AFTMARKAR, $=\alpha+\beta_{1} E X A N T E+\beta_{2} O V R S_{i}+\beta_{3} P S O_{i}+\beta_{4} M V_{i}+\beta_{5} C O N T_{i}+\beta_{6} I N D_{i}+$ $\beta_{7} a r_{i}+\varepsilon_{i}$

where $A F T M A R K A R_{i, T}$ is the aftermarket abnormal return of firm $i$ over $T$ period (one-year), which takes several forms according to the method of calculation, and $a r_{i}$ is the initial abnormal return of firm $i$.

\section{EMPIRICAL RESULTS}

\section{A. Initial Abnormal Returns}

42. The mean initial abnormal return for the IPO sample is 290 percent (Table 5, Panel A). This is the average return obtained by an investor subscribing to the average IPOs at the offer price and selling the shares at the end of the first trading day. The results from the $t$-statistic reveal that the mean initial abnormal return is significantly different from zero at the one-percent level. However, since initial returns are not normally distributed and are characterized by positive skewness, as discussed in Section IV, the relevance of the structural parameters estimated based on the $t$-statistic should be treated with caution. To check the

\footnotetext{
${ }^{23}$ Timing is excluded from the model since most of the IPOs in the sample with one-year return data occurred during booming years.

${ }^{24}$ Levis (1993) and Paudyal and others (1998) argue that, to the extent that initial abnormal returns were due to initial over-optimism in the market, such issues should underperform the market in the long run. In contrast, if the initial price reflects the equilibrium value of the IPO stock, its long-run performance should not be significantly different from the market's performance.
} 
robustness of these results, the non-parametric Wilcoxon signed-rank test is used and it obtains similar results. The median initial abnormal return is around 147 percent, and the test statistic rejects the null hypothesis of no significant median initial abnormal returns at the one-percent level. Also, the results show that around 98 percent of IPOs (46 out of 47) had positive initial abnormal returns. The mean WR ratio of around 3.32 implies that an investor would have had to invest 70 percent less in each IPO than in each corresponding reference portfolio to achieve the same wealth after the close of the first trading day. The evidence from these findings indicates that the IPOs in the GCC are underpriced, in line with the findings reported in the literature for most IPOs, but the level of underpricing is by far higher than in other countries. ${ }^{25}$

Table 5. Initial Abnormal Returns of IPOs in the GCC

\begin{tabular}{|c|c|c|c|c|c|c|c|}
\hline \multicolumn{8}{|c|}{ Panel A: Entire sample (47 firms) } \\
\hline $\begin{array}{l}\text { Firms with }>0 \\
\text { abnormal return }\end{array}$ & $\begin{array}{l}\text { Firms with } \leq 0 \\
\text { abnormal return }\end{array}$ & Mean & $t$-stat & Median & z-stat & Mean WR ratio & Median WR ratio \\
\hline 46 & 1 & 2.90 & $6.14^{* * *}$ & 1.47 & $5.89^{\star * *}$ & 3.32 & 2.36 \\
\hline \multicolumn{8}{|c|}{ Panel B: Comparison of IPOs' initial abnormal returns classified by country } \\
\hline $\begin{array}{l}\text { Number of IPOs in } \\
\text { booming stock } \\
\text { markets } \\
\text { (non-booming) }\end{array}$ & \multicolumn{2}{|c|}{$\begin{array}{l}\text { Mean of IPOs in } \\
\text { booming stock } \\
\text { markets } \\
\text { (Median) } \\
\end{array}$} & \multicolumn{2}{|c|}{$\begin{array}{l}\text { Mean of IPOs in non- } \\
\text { booming stock } \\
\text { markets } \\
\text { (Median) } \\
\end{array}$} & $\begin{array}{l}\text { Difference in medians } \\
\text { (booming markets- } \\
\text { non-booming) }\end{array}$ & $\begin{array}{l}t \text {-stat for } \\
\text { difference } \\
\text { in means }\end{array}$ & $\begin{array}{l}\text { Mann-Whitney test for } \\
\text { difference in medians } \\
\text { average rank }\end{array}$ \\
\hline $\begin{array}{l}33 \\
(14)\end{array}$ & \multicolumn{2}{|l|}{$\begin{array}{l}3.80 \\
(2.4)\end{array}$} & \multicolumn{2}{|c|}{$\begin{array}{l}0.8 \\
(0.6)\end{array}$} & $\begin{array}{l}3.01 \\
(1.8)\end{array}$ & $3.2^{* \star *}$ & $29.4-11.30^{* * *}$ \\
\hline \multicolumn{8}{|c|}{ Panel C: Comparison of IPOs' initial abnormal returns classified by year } \\
\hline $\begin{array}{l}\text { Number of IPOs in } \\
\text { booming years } \\
\text { (non-booming) }\end{array}$ & \multicolumn{2}{|c|}{$\begin{array}{l}\text { Mean of IPOs in } \\
\text { booming years } \\
\text { (Median) }\end{array}$} & \multicolumn{2}{|c|}{$\begin{array}{l}\text { Mean of IPOs in non- } \\
\text { booming years } \\
\text { (Median) }\end{array}$} & $\begin{array}{l}\text { Difference in medians } \\
\text { (booming years- } \\
\text { non-booming) }\end{array}$ & $\begin{array}{l}t \text {-stat for } \\
\text { difference } \\
\text { in means } \\
\end{array}$ & $\begin{array}{l}\text { Mann-Whitney test for } \\
\text { difference in medians } \\
\text { average rank }\end{array}$ \\
\hline $\begin{array}{l}34 \\
(13)\end{array}$ & \multicolumn{2}{|c|}{$\begin{array}{l}3.5 \\
(2.1)\end{array}$} & \multicolumn{2}{|l|}{$\begin{array}{l}1.32 \\
(1.22)\end{array}$} & $\begin{array}{l}2.19 \\
(0.88)\end{array}$ & $2.16^{* *}$ & $26.24-18.15^{*}$ \\
\hline \multicolumn{8}{|c|}{ Panel D: Comparison of IPOs' initial abnormal returns classified by the median of the oversubscription multiple } \\
\hline $\begin{array}{l}\text { Number of IPOs } \\
\text { above } \\
\text { (below) }\end{array}$ & \multicolumn{2}{|c|}{$\begin{array}{l}\text { Mean of IPOs above } \\
\text { (Median) }\end{array}$} & \multicolumn{2}{|c|}{$\begin{array}{l}\text { Mean of IPOs below } \\
\text { (Median) }\end{array}$} & $\begin{array}{l}\text { Difference in medians } \\
\text { (above-below) }\end{array}$ & $\begin{array}{l}\text {-stat for } \\
\text { difference } \\
\text { in means } \\
\end{array}$ & $\begin{array}{l}\text { Mann-Whitney test for } \\
\text { difference in medians } \\
\text { average rank }\end{array}$ \\
\hline $\begin{array}{l}25 \\
(22)\end{array}$ & \multicolumn{2}{|l|}{$\begin{array}{l}3.04 \\
(1.93)\end{array}$} & \multicolumn{2}{|l|}{$\begin{array}{l}2.73 \\
(0.97) \\
\end{array}$} & $\begin{array}{l}0.31 \\
(0.96)\end{array}$ & 0.32 & 27.4-20.1 \\
\hline \multicolumn{8}{|c|}{ Panel E: Comparison of IPOs' initial abnormal returns classified by industry } \\
\hline $\begin{array}{l}\text { Number of IPOs in } \\
\text { regulated industries } \\
\text { (non-regulated) }\end{array}$ & \multicolumn{2}{|c|}{$\begin{array}{l}\text { Mean of IPOs in } \\
\text { regulated industries } \\
\text { (Median) }\end{array}$} & \multicolumn{2}{|c|}{$\begin{array}{l}\text { Mean of IPOs in non- } \\
\text { regulated industries } \\
\text { (Median) }\end{array}$} & $\begin{array}{l}\text { Difference in medians } \\
\text { (regulated-non- } \\
\text { regulated) }\end{array}$ & $\begin{array}{l}\text {-stat for } \\
\text { difference } \\
\text { in means }\end{array}$ & $\begin{array}{l}\text { Mann-Whitney test for } \\
\text { difference in medians } \\
\text { average rank }\end{array}$ \\
\hline $\begin{array}{l}30 \\
(17)\end{array}$ & \multicolumn{2}{|l|}{$\begin{array}{l}3.39 \\
(1.73)\end{array}$} & \multicolumn{2}{|l|}{$\begin{array}{l}2.03 \\
(1.23)\end{array}$} & $\begin{array}{l}1.40 \\
(0.5)\end{array}$ & 0.32 & 25.1-22 \\
\hline
\end{tabular}

${ }^{* \star *},{ }^{* *}$, and ${ }^{*}$ Significant at the 1,5 and 10 percent level, respectively.

43. The results indicate that firms that went public in the booming markets (Qatar, Saudi Arabia, and U.A.E.) outperform those that went public in the less "hot markets" (Table 5, Panel B). The mean (median) initial abnormal return for the first sample is 380 (240) percent versus 80 (60) percent for the second sample. Both $t$-statistic and the Mann-Whitney test

${ }^{25}$ See for example, Loughran and others, 1994. 
confirm a significant difference between the two samples at the one-percent level. Similar results are found for those firms that went public in bull years versus those went public in bear years (Table 5, Panel C). Firms that experience higher oversubscription provide investors with higher abnormal initial returns. However, the test statistics fail to find any significant differences between the two samples (Table 5, Panel D). ${ }^{26}$ Similarly, firms that are classified as regulated industries perform better then those related to unregulated industries, although the difference is not significant at any level (Table 5, Panel E).

44. The results of estimating equation (18) on the determinants of the initial abnormal returns of IPOs are presented in Table $6 .{ }^{27}$ The data met the underlying assumption of OLS. Both the Breusch-Pagan LM test and White's test confirm the heteroskedasticity of the variance of the residuals. To compute robust variance estimates, White's heteroskedasticity consistent standard errors (HCSE) test was used. ${ }^{28}$

\section{Table 6. Multivariate Cross-Sectional Regression Analysis for the Determinants of Initial Abnormal Returns of IPOs}

\begin{tabular}{|c|c|c|}
\hline \multirow{2}{*}{ Independent variables } & \multicolumn{2}{|c|}{ Dependent variable: Initial abnormal returns } \\
\hline & Coefficient & t-statistic \\
\hline Intercept & -4.96 & $(-2.17)^{\star \star}$ \\
\hline EXANTE & 45.8 & (1.18) \\
\hline PSO & 3.1 & $(1.2)$ \\
\hline$M V$ & -2.94 & $(-0.06)$ \\
\hline OVRS & 0.0004 & $(0.17)$ \\
\hline CONT & 2.82 & $(3.02)^{\star * *}$ \\
\hline TIM & 1.96 & $(2.37)^{\star *}$ \\
\hline IND & 2.32 & $(2.47)^{* *}$ \\
\hline$R^{2}$ (percent) & 43.85 & \\
\hline Adj. $R^{2}$ (percent) & 32.03 & \\
\hline$F$-value & $3.71^{* * *}$ & \\
\hline Number of observations & 47 & \\
\hline
\end{tabular}

\footnotetext{
${ }^{26}$ This result could be influenced by the experience of massive oversubscriptions in the regions. Retail investors are allocated consistently the minimum in most IPOs regardless of the amounts requested, thus reducing the incentives for increasing the amounts demanded.

${ }^{27}$ Equation (18) was estimated using several different specifications. Some of the independent variables were excluded in order to observe whether the parameters of the remaining variables were driven by any autocorrelation. The results of these alternative specifications were similar to the ones presented in Table 6 , thus rejecting the hypothesis that the lack of significance of the traditional explanatory variables was due to autocorrelation with CONT, TIM or IND. The same applies to equation (19) on the determinants of aftermarket performance.

${ }^{28}$ See White, 1980.
} 
45. None of the independent variables that have been identified as determinants of IPOs' initial abnormal returns in the literature has a measurable impact on the level of underpricing of GCC IPOs. However, country specific characteristics, the timing of offers, and the nature of the firm's industry have a significant impact on the level of underpricing at the one- and five-percent levels (Table 6). The sign of these variables are consistent with the findings from the parametric $t$-test and the non-parametric Mann-Whitney test. Specifically, firms that went public in bull markets, during booming years, and from regulated industries experience a higher level of underpricing. The level of oversubscription and the proportion of shares offered do not seem to affect the level of excess initial returns in the GCC IPOs, neither does the volatility of the market (ex-ante uncertainty and market volatility). Thus, GCC investors seem to be driven mainly by market trends (whether booming or not) and the regulated nature of the firm's economic sector rather than by risk, expected demand, or the firm's "signaling."

\section{B. Aftermarket Abnormal Performance}

46. The purpose of this part is to answer two questions. First, do IPOs sustain their initial abnormal returns and provide investors with positive abnormal returns over a long period of time? Second, how can the long-run performance of IPOs be explained and what are the exogenous variables that might affect such returns?

47. As to the first question, the results given in Table 7 show the long-run abnormal returns of IPOs over one year including initial returns (Panel A) and excluding initial returns (Panel B). Panels $\mathrm{C}$ to $\mathrm{R}$ show the results of comparison of aftermarket abnormal returns, excluding initial returns, of each group of firms classified by country, oversubscription level, industry, and the level of underpricing or initial abnormal return. 
Table 7. Aftermarket Abnormal Returns of IPOs in the GCC

\begin{tabular}{|c|c|c|c|c|c|c|}
\hline \multicolumn{7}{|c|}{ Panel A: 12 months cumulative and buy-and-hold abnormal returns including initial returns (29 firms) } \\
\hline & & \multicolumn{2}{|c|}{ Abnormal Results Model } & & \multicolumn{2}{|c|}{ CAPM } \\
\hline & & CAR & BHAR & & CAR & BHAR \\
\hline \multicolumn{2}{|c|}{ Firms with $>0$ abnormal return } & 23 & 27 & & 28 & 27 \\
\hline \multicolumn{2}{|c|}{ Firms with $\leq 0$ abnormal return } & 6 & 2 & & 1 & 2 \\
\hline \multicolumn{2}{|c|}{ Mean abnormal returns } & 2.75 & 2.8 & & 3.1 & 3.2 \\
\hline \multicolumn{2}{|l|}{$t$ - statistics } & $4.03^{* * *}$ & $4.2^{* \star *}$ & & $4.7^{* * *}$ & $4.9^{* * *}$ \\
\hline \multicolumn{2}{|c|}{ Median abnormal returns } & 1.1 & 1.8 & & 1.45 & 2.0 \\
\hline \multicolumn{2}{|l|}{ z- statistic } & $3.90^{* \star *}$ & $4.2^{\star \star \star}$ & & $4.7^{\star * *}$ & $4.6^{* * *}$ \\
\hline \multicolumn{2}{|l|}{ Mean WR ratio } & & 2.33 & & & \\
\hline \multicolumn{2}{|l|}{ Median WR ratio } & & 1.98 & & & \\
\hline \multicolumn{7}{|c|}{ Panel B: 12 months cumulative and buy-and-hold abnormal returns excluding initial returns (29 firms) } \\
\hline & & \multicolumn{2}{|c|}{ Abnormal Results Model } & & \multicolumn{2}{|c|}{ CAPM } \\
\hline & & CAR & BHAR & & CAR & BHAR \\
\hline \multicolumn{2}{|c|}{ Firms with $>0$ abnormal return } & 7 & 9 & & 10 & 14 \\
\hline \multicolumn{2}{|c|}{ Firms with $\leq 0$ abnormal return } & 22 & 20 & & 19 & 15 \\
\hline \multicolumn{2}{|c|}{ Mean abnormal returns } & -0.50 & -0.23 & & -0.25 & -0.07 \\
\hline \multicolumn{2}{|c|}{$t$ - statistics } & $-3.6^{* * *}$ & $-2.1^{* *}$ & & $-2.4^{* *}$ & -0.82 \\
\hline \multicolumn{2}{|c|}{ Median abnormal returns } & -0.47 & -0.25 & & -0.21 & -0.08 \\
\hline \multicolumn{2}{|c|}{ z- statistic } & $-3.1^{\star \star *}$ & $-2.00^{* *}$ & & $-2.20^{* *}$ & -0.73 \\
\hline \multicolumn{2}{|l|}{ Mean WR ratio } & & 0.84 & & & \\
\hline \multicolumn{2}{|l|}{ Median WR ratio } & & 0.79 & & & \\
\hline \multicolumn{7}{|c|}{ Panel C: Comparison of IPOs' cumulative abnormal returns classified by country } \\
\hline $\begin{array}{l}\text { Number of IPOs in } \\
\text { booming stock } \\
\text { markets } \\
\text { (non-booming) }\end{array}$ & $\begin{array}{l}\text { Mean of IPOs in } \\
\text { booming stock } \\
\text { markets } \\
\text { (Median) }\end{array}$ & $\begin{array}{l}\text { Mean of IPOs in non- } \\
\text { booming stock } \\
\text { markets } \\
\text { (Median) }\end{array}$ & $\begin{array}{l}\text { Difference between } \\
\text { the means "medians" } \\
\text { (booming markets- } \\
\text { non-booming) }\end{array}$ & $\begin{array}{l}t \text {-stat for } \\
\text { difference } \\
\text { in means }\end{array}$ & \multicolumn{2}{|c|}{$\begin{array}{l}\text { Mann-Whitney test for } \\
\text { difference in medians } \\
\text { average rank }\end{array}$} \\
\hline $\begin{array}{l}22 \\
(7)\end{array}$ & $\begin{array}{l}-0.51 \\
(-0.47)\end{array}$ & $\begin{array}{l}-0.48 \\
(-0.47)\end{array}$ & $\begin{array}{l}-0.03 \\
(0)\end{array}$ & -0.8 & \multicolumn{2}{|c|}{$14.9-15.2$} \\
\hline \multicolumn{7}{|c|}{ Panel D: Comparison of IPOs' buy-and-hold abnormal returns classified by country } \\
\hline $\begin{array}{l}\text { Number of IPOs in } \\
\text { booming stock } \\
\text { markets } \\
\text { (non-booming) }\end{array}$ & $\begin{array}{l}\text { Mean of IPOs in } \\
\text { booming stock } \\
\text { markets } \\
\text { (Median) }\end{array}$ & $\begin{array}{l}\text { Mean of IPOs in non- } \\
\text { booming stock } \\
\text { markets } \\
\text { (Median) }\end{array}$ & $\begin{array}{l}\text { Difference between } \\
\text { the means "medians" } \\
\text { (booming markets- } \\
\text { non-booming) }\end{array}$ & $\begin{array}{l}t \text {-stat for } \\
\text { difference } \\
\text { in means }\end{array}$ & \multicolumn{2}{|c|}{$\begin{array}{l}\text { Mann-Whitney test for } \\
\text { difference in medians } \\
\text { average rank }\end{array}$} \\
\hline $\begin{array}{l}22 \\
(7)\end{array}$ & $\begin{array}{l}-0.22 \\
(-0.27)\end{array}$ & $\begin{array}{l}-0.23 \\
(-0.24)\end{array}$ & $\begin{array}{l}0.01 \\
(-0.03)\end{array}$ & 0.04 & \multicolumn{2}{|c|}{$14.9-15.1$} \\
\hline Panel E: Compari & of of IPOs' CAPI & nulative abnormal $\mathrm{re}$ & urns classified by $\mathrm{c}$ & untry & & \\
\hline $\begin{array}{l}\text { Number of IPOs in } \\
\text { booming stock } \\
\text { markets } \\
\text { (non-booming) }\end{array}$ & $\begin{array}{l}\text { Mean of IPOs in } \\
\text { booming stock } \\
\text { markets } \\
\text { (Median) } \\
\end{array}$ & $\begin{array}{l}\text { Mean of IPOs in non- } \\
\text { booming stock } \\
\text { markets } \\
\text { (Median) } \\
\end{array}$ & $\begin{array}{l}\text { Difference between } \\
\text { the means "medians" } \\
\text { (booming markets- } \\
\text { non-booming) }\end{array}$ & $\begin{array}{l}t \text {-stat for } \\
\text { difference } \\
\text { in means }\end{array}$ & & est for \\
\hline $\begin{array}{l}22 \\
(7)\end{array}$ & $\begin{array}{l}-0.39 \\
(-0.45)\end{array}$ & $\begin{array}{l}0.02 \\
(-0.04)\end{array}$ & $\begin{array}{l}0.41 \\
(-0.41)\end{array}$ & -1.33 & & \\
\hline Panel F: Compari & of of IPOs' CAPI & /-and-hold abnorma & returns classified by & country & & \\
\hline $\begin{array}{l}\text { Number of IPOs in } \\
\text { booming stock } \\
\text { markets } \\
\text { (non-booming) }\end{array}$ & $\begin{array}{l}\text { Mean of IPOs in } \\
\text { booming stock } \\
\text { markets } \\
\text { (Median) } \\
\end{array}$ & $\begin{array}{l}\text { Mean of IPOs in non- } \\
\text { booming stock } \\
\text { markets } \\
\text { (Median) }\end{array}$ & $\begin{array}{l}\text { Difference between } \\
\text { the means "medians" } \\
\text { (booming markets- } \\
\text { non-booming) }\end{array}$ & $\begin{array}{l}t \text {-stat for } \\
\text { difference } \\
\text { in means }\end{array}$ & & $\begin{array}{l}\text { est for } \\
\text { dians }\end{array}$ \\
\hline $\begin{array}{l}22 \\
(7)\end{array}$ & $\begin{array}{l}-0.17 \\
(-0.30)\end{array}$ & $\begin{array}{l}0.09 \\
(0.04)\end{array}$ & $\begin{array}{l}-0.27 \\
(-0.34)\end{array}$ & -1.04 & & \\
\hline
\end{tabular}




\begin{tabular}{|c|c|c|c|c|c|}
\hline \multicolumn{6}{|c|}{ Panel G: Comparison of IPOs' cumulative abnormal returns classified by the median number of oversubscription } \\
\hline $\begin{array}{l}\text { Number of IPOs } \\
\text { below } \\
\text { (above) }\end{array}$ & $\begin{array}{l}\text { Mean of IPOs below } \\
\text { (Median) }\end{array}$ & $\begin{array}{l}\text { Mean of IPOs above } \\
\text { (Median) }\end{array}$ & $\begin{array}{l}\text { Difference between } \\
\text { the means "medians" } \\
\text { (below- above) }\end{array}$ & $\begin{array}{l}\text {-stat for } \\
\text { difference } \\
\text { in means }\end{array}$ & $\begin{array}{l}\text { Mann-Whitney test for } \\
\text { difference in medians } \\
\text { average rank }\end{array}$ \\
\hline $\begin{array}{l}14 \\
(15)\end{array}$ & $\begin{array}{l}-0.64 \\
(-0.58)\end{array}$ & $\begin{array}{l}-0.38 \\
(-0.44)\end{array}$ & $\begin{array}{l}-0.26 \\
(-0.14)\end{array}$ & -0.93 & 13.8-16.3 \\
\hline \multicolumn{6}{|c|}{ Panel H: Comparison of IPOs' buy-and-hold abnormal returns classified by the median number of oversubscription } \\
\hline $\begin{array}{l}\text { Number of IPOs } \\
\text { below } \\
\text { (above) }\end{array}$ & $\begin{array}{l}\text { Mean of IPOs below } \\
\text { (Median) }\end{array}$ & $\begin{array}{l}\text { Mean of IPOs above } \\
\text { (Median) }\end{array}$ & $\begin{array}{l}\text { Difference between } \\
\text { the means "medians" } \\
\text { (below- above) }\end{array}$ & $\begin{array}{l}\text {-stat for } \\
\text { difference } \\
\text { in means }\end{array}$ & $\begin{array}{l}\text { Mann-Whitney test for } \\
\text { difference in medians } \\
\text { average rank }\end{array}$ \\
\hline $\begin{array}{l}14 \\
(15)\end{array}$ & $\begin{array}{l}-0.40 \\
(-0.43)\end{array}$ & $\begin{array}{l}-0.08 \\
(-0.12)\end{array}$ & $\begin{array}{l}-0.32 \\
(-0.31)\end{array}$ & -1.51 & 12.9-16.9 \\
\hline \multicolumn{6}{|c|}{ Panel I: Comparison of IPOs' CAPM cumulative returns classified by the median number of oversubscription } \\
\hline $\begin{array}{l}\text { Number of IPOs } \\
\text { below } \\
\text { (above) }\end{array}$ & $\begin{array}{l}\text { Mean of IPOs below } \\
\text { (Median) }\end{array}$ & $\begin{array}{l}\text { Mean of IPOs above } \\
\text { (Median) }\end{array}$ & $\begin{array}{l}\text { Difference between } \\
\text { the means "medians" } \\
\text { (below- above) }\end{array}$ & $\begin{array}{l}t \text {-stat for } \\
\text { difference } \\
\text { in means }\end{array}$ & $\begin{array}{l}\text { Mann-Whitney test for } \\
\text { difference in medians } \\
\text { average rank }\end{array}$ \\
\hline $\begin{array}{l}14 \\
(15)\end{array}$ & $\begin{array}{l}-0.43 \\
(-0.42)\end{array}$ & $\begin{array}{l}-0.09 \\
(-0.10)\end{array}$ & $\begin{array}{l}-0.34 \\
(-0.32)\end{array}$ & -1.63 & 12.4-17.4 \\
\hline
\end{tabular}

Panel J: Comparison of IPOs' CAPM buy-and-hold abnormal returns classified by the median number of oversubscription

\begin{tabular}{lllll}
\hline $\begin{array}{l}\text { Number of IPOs } \\
\text { below } \\
\text { (above) }\end{array}$ & $\begin{array}{l}\text { Mean of IPOs below } \\
\text { (Median) }\end{array}$ & $\begin{array}{l}\text { Mean of IPOs above } \\
\text { (Median) }\end{array}$ & $\begin{array}{l}\text { Difference between } \\
\text { the means "medians" } \\
\text { (below- above) }\end{array}$ & $\begin{array}{l}t \text {-stat for } \\
\text { difference } \\
\text { in means }\end{array}$ \\
\hline 14 & -0.26 & 0.10 & -0.37 & $\begin{array}{l}\text { Mann-Whitney test for } \\
\text { difference in medians } \\
\text { average rank }\end{array}$ \\
$(15)$ & $(-0.25)$ & $(0.15)$ & $(-0.4)$ & $-2.15^{* *}$ \\
\hline
\end{tabular}

\begin{tabular}{|c|c|c|c|c|c|}
\hline \multicolumn{6}{|c|}{ Panel K: Comparison of IPOs' cumulative abnormal returns classified by industry } \\
\hline $\begin{array}{l}\text { Number of IPOs in } \\
\text { regulated industries } \\
\text { (non-regulated) }\end{array}$ & $\begin{array}{l}\text { Mean of IPOs in } \\
\text { regulated industries } \\
\text { (Median) }\end{array}$ & $\begin{array}{l}\text { Mean of IPOs in non- } \\
\text { regulated industries } \\
\text { (Median) }\end{array}$ & $\begin{array}{l}\text { Difference between } \\
\text { the means "medians" } \\
\text { (regulated-non- } \\
\text { regulated) }\end{array}$ & $\begin{array}{l}t \text {-stat for } \\
\text { difference } \\
\text { in means }\end{array}$ & $\begin{array}{l}\text { Mann-Whitney test for } \\
\text { difference in medians } \\
\text { average rank }\end{array}$ \\
\hline $\begin{array}{l}20 \\
(9)\end{array}$ & $\begin{array}{l}-0.68 \\
(-0.56)\end{array}$ & $\begin{array}{l}-0.1 \\
(-0.35)\end{array}$ & $\begin{array}{l}-0.58 \\
(-0.21)\end{array}$ & $-2.03^{* *}$ & $13.3-18.8$ \\
\hline
\end{tabular}

\section{Panel L: Comparison of IPOs' buy-and-hold abnormal returns classified by industry}

\begin{tabular}{lllll}
\hline $\begin{array}{l}\text { Number of IPOs in } \\
\text { regulated industries } \\
\text { (non-regulated) }\end{array}$ & $\begin{array}{l}\text { Mean of IPOs in } \\
\text { regulated industries } \\
\text { (Median) }\end{array}$ & $\begin{array}{l}\text { Mean of IPOs in non- } \\
\text { regulated industries } \\
\text { (Median) }\end{array}$ & $\begin{array}{l}\text { Difference between } \\
\text { the means "medians" } \\
\text { (regulated-non- } \\
\text { regulated) }\end{array}$ & $\begin{array}{l}t \text {-stat for } \\
\text { difference } \\
\text { in means }\end{array}$ \\
\hline $\begin{array}{l}20 \\
(9)\end{array}$ & $\begin{array}{l}-0.36 \\
(-0.36)\end{array}$ & $\begin{array}{l}\text { Mann-Whitney test for } \\
\text { difference in medians } \\
\text { average rank }\end{array}$ & -0.42 & $-1.84^{*}$ \\
$(0.33)$ & $(-0.69)$ & $13.3-18.9^{*}$
\end{tabular}

Panel M: Comparison of IPOs' CAPM cumulative abnormal returns classified by industry

\begin{tabular}{|c|c|c|c|c|c|}
\hline $\begin{array}{l}\text { Number of IPOs in } \\
\text { regulated industries } \\
\text { (non-regulated) }\end{array}$ & $\begin{array}{l}\text { Mean of IPOs in } \\
\text { regulated industries } \\
\text { (Median) }\end{array}$ & $\begin{array}{l}\text { Mean of IPOs in non- } \\
\text { regulated industries } \\
\text { (Median) }\end{array}$ & $\begin{array}{l}\text { Difference between } \\
\text { the means "medians" } \\
\text { (regulated-non- } \\
\text { regulated) }\end{array}$ & $\begin{array}{l}t \text {-stat for } \\
\text { difference } \\
\text { in means }\end{array}$ & $\begin{array}{l}\text { Mann-Whitney test for } \\
\text { difference in medians } \\
\text { average rank }\end{array}$ \\
\hline $\begin{array}{l}20 \\
(9)\end{array}$ & $\begin{array}{l}-0.33 \\
(-0.24)\end{array}$ & $\begin{array}{l}-0.09 \\
(-0.13)\end{array}$ & $\begin{array}{l}-0.24 \\
(-0.11)\end{array}$ & -1.05 & 14.1-17.1 \\
\hline \multicolumn{6}{|c|}{ Panel N: Comparison of IPOs' CAPM buy-and-hold abnormal returns classified by industry } \\
\hline $\begin{array}{l}\text { Number of IPOs in } \\
\text { regulated industries } \\
\text { (non-regulated) }\end{array}$ & $\begin{array}{l}\text { Mean of IPOs in } \\
\text { regulated industries } \\
\text { (Median) }\end{array}$ & $\begin{array}{l}\text { Mean of IPOs in non- } \\
\text { regulated industries } \\
\text { (Median) }\end{array}$ & $\begin{array}{l}\text { Difference between } \\
\text { the means "medians" } \\
\text { (regulated-non- } \\
\text { regulated) }\end{array}$ & $\begin{array}{l}t \text {-stat for } \\
\text { difference } \\
\text { in means }\end{array}$ & $\begin{array}{l}\text { Mann-Whitney test for } \\
\text { difference in medians } \\
\text { average rank }\end{array}$ \\
\hline $\begin{array}{l}20 \\
(9)\end{array}$ & $\begin{array}{l}-0.13 \\
(-0.14)\end{array}$ & $\begin{array}{l}0.05 \\
(0.23)\end{array}$ & $\begin{array}{l}-0.19 \\
(-0.37)\end{array}$ & -0.96 & 13.8-17.8 \\
\hline \multicolumn{6}{|c|}{ Panel O: Comparison of IPOs' cumulative abnormal returns classified by initial abnormal returns' median } \\
\hline $\begin{array}{l}\text { Number of IPOs } \\
\text { below } \\
\text { (above) }\end{array}$ & $\begin{array}{l}\text { Mean of IPOs below } \\
\text { (Median) }\end{array}$ & $\begin{array}{l}\text { Mean of IPOs above } \\
\text { (Median) }\end{array}$ & $\begin{array}{l}\text { Difference between } \\
\text { the means "medians" } \\
\text { (below- above) }\end{array}$ & $\begin{array}{l}t \text {-stat for } \\
\text { difference } \\
\text { in means }\end{array}$ & $\begin{array}{l}\text { Mann-Whitney test for } \\
\text { difference in medians } \\
\text { average rank }\end{array}$ \\
\hline $\begin{array}{l}14 \\
(15)\end{array}$ & $\begin{array}{l}-0.53 \\
(-0.57)\end{array}$ & $\begin{array}{l}-0.48 \\
(-0.47)\end{array}$ & $\begin{array}{l}-0.06 \\
(-0.1)\end{array}$ & -.20 & 14.8-15.2 \\
\hline
\end{tabular}




\begin{tabular}{|c|c|c|c|c|c|}
\hline \multicolumn{6}{|c|}{ Panel P: Comparison of IPOs' buy-and-hold abnormal returns classified by initial abnormal returns' median } \\
\hline $\begin{array}{l}\text { Number of IPOs } \\
\text { below } \\
\text { (above) }\end{array}$ & $\begin{array}{l}\text { Mean of IPOs below } \\
\text { (Median) }\end{array}$ & $\begin{array}{l}\text { Mean of IPOs above } \\
\text { (Median) }\end{array}$ & $\begin{array}{l}\text { Difference between } \\
\text { the means "medians" } \\
\text { (below- above) }\end{array}$ & $\begin{array}{l}\text {-stat for } \\
\text { difference } \\
\text { in means }\end{array}$ & $\begin{array}{l}\text { Mann-Whitney test for } \\
\text { difference in medians } \\
\text { average rank }\end{array}$ \\
\hline $\begin{array}{l}14 \\
(15)\end{array}$ & $\begin{array}{l}-0.20 \\
(-0.23)\end{array}$ & $\begin{array}{l}-0.26 \\
(-0.30)\end{array}$ & $\begin{array}{l}0.06 \\
(0.07)\end{array}$ & 0.30 & 15.2-14.8 \\
\hline \multicolumn{6}{|c|}{ Panel Q: Comparison of IPOs' CAPM cumulative abnormal returns classified by initial abnormal returns' median } \\
\hline $\begin{array}{l}\text { Number of IPOs } \\
\text { below } \\
\text { (above) }\end{array}$ & $\begin{array}{l}\text { Mean of IPOs below } \\
\text { (Median) }\end{array}$ & $\begin{array}{l}\text { Mean of IPOs above } \\
\text { (Median) }\end{array}$ & $\begin{array}{l}\text { Difference between } \\
\text { the means "medians" } \\
\text { (below- above) }\end{array}$ & $\begin{array}{l}\text {-stat for } \\
\text { difference } \\
\text { in means }\end{array}$ & $\begin{array}{l}\text { Mann-Whitney test for } \\
\text { difference in medians } \\
\text { average rank }\end{array}$ \\
\hline $\begin{array}{l}14 \\
(15)\end{array}$ & $\begin{array}{l}-0.21 \\
(-0.17)\end{array}$ & $\begin{array}{l}-0.30 \\
(-0.26)\end{array}$ & $\begin{array}{l}0.10 \\
(0.09)\end{array}$ & 0.45 & $15.8-14.2$ \\
\hline \multicolumn{6}{|c|}{ Panel R: Comparison of IPOs' CAPM buy-and-hold abnormal returns classified by initial abnormal returns' median } \\
\hline $\begin{array}{l}\begin{array}{l}\text { Number of IPOs } \\
\text { below } \\
\text { (above) }\end{array} \\
\end{array}$ & $\begin{array}{l}\text { Mean of IPOs below } \\
\text { (Median) }\end{array}$ & $\begin{array}{l}\text { Mean of IPOs above } \\
\text { (Median) }\end{array}$ & $\begin{array}{l}\text { Difference between } \\
\text { the means "medians" } \\
\text { (below- above) }\end{array}$ & $\begin{array}{l}t \text {-stat for } \\
\text { difference } \\
\text { in means }\end{array}$ & $\begin{array}{l}\text { Mann-Whitney test for } \\
\text { difference in medians } \\
\text { average rank }\end{array}$ \\
\hline $\begin{array}{l}14 \\
(15)\end{array}$ & $\begin{array}{l}0.01 \\
(0.1)\end{array}$ & $\begin{array}{l}-0.15 \\
(-0.26)\end{array}$ & $\begin{array}{l}0.16 \\
(0.36)\end{array}$ & 0.91 & $16.6-13.5$ \\
\hline
\end{tabular}

48. Including initial returns, GCC IPOs yielded positive returns over a one-year period (Table 7, Panel A). These returns are higher, on average, when calculated with the BHAR method. Both the parametric test statistics and the non-parametric Wilcoxon signed-rank test are significant at the one-percent level for all models, which means that investors who subscribed to IPOs at the offer price and sold them one year after the first listing day outperformed the market. The average aftermarket abnormal return for the investor is around 280 percent using both BHAR and CAR. The average WR ratio of around 2.33 implies that an investor would have had to invest 57 percent less in each IPO than in each corresponding reference portfolio to achieve the same wealth after one year of official listing.

49. Since investors usually get only a fraction of the amount of shares they apply for during the subscription period, it is relevant to repeat the same exercise after excluding the initial returns, which could be obtained just for the portion of the IPO allocated to the investor during the subscription period. Excluding initial returns, after-market abnormal returns of GCC IPOs over a one-year period have been significant and negative (Table 7, Panel B). The null hypothesis that the mean (median) abnormal returns are not different from zero is rejected at the one and five percent levels for most models. Both the $t$-statistic and $z$ statistic are negative, implying that IPOs underperform the market in the long run. The IPOs average WR ratio of 0.84 implies that an investor would have to invest 19 percent more to get the same performance as the market. Such results support the idea that at some point after going public the abnormal returns on IPOs may be negative (see among others, Ritter, 1991).

50. The results of splitting the sample firms according to market climate (country); level of oversubscription; industry classifications; and level of underpricing, in order to investigate whether the aftermarket performance (excluding initial returns) might be affected by any of the classifications mentioned-above, show that firms that went public in the booming markets (Qatar, Saudi Arabia, and the U.A.E.) underperformed those that went public in the 
less "hot markets," although the parameters are not significant at any level and under no model (Table 7, Panels C-F).

51. Firms that experience higher oversubscription levels provide investors with higher long-run abnormal returns, although this relationship is significant at the five-percent level only for the BHAR method using the CAPM model (Table 7, Panels G-J). This in fact contradicts the theoretical argument that the positive sentiment of investors is expected to diminish over time when they recognize that they were overoptimistic when subscribing heavily to buy IPOs. Furthermore, these results are not consistent with the recent findings of Agarwal, Liu, and Rhee (2006) who indicate that IPOs with high oversubscription have large negative long-run abnormal returns compared with IPOs with lower levels of oversubscription. In the case of GCC IPOs, this could be partially explained by the large differences in size of firms participating in IPOs. A very large oversubscription multiple could be the result of the relatively small size of the firm or offering vis-à-vis the excess liquidity in the market, and not necessarily a reflection of a particularly large underpricing of the IPO.

52. Firms that are classified as regulated industries perform worse than those related to unregulated industries. The relationship is significant only using the risk-unadjusted models at the one- and five- percent levels (Table 7, Panels K-N). This could result from the higher level of underpricing of IPOs in regulated industries (Table 5, Panel E). Finally, there seems to be no significant difference between firms that experienced higher initial abnormal returns and those with lower initial abnormal returns (Table 7, Panels O-R).

53. The identification of the determinants of the after-market abnormal performance of GCC IPOs is done by estimating equation (19). Unlike in the case of initial returns where we find a heteroskedastic covariance matrix, the variance of the residuals is homoskedastic. Therefore, the OLS technique is employed. However, three observations were excluded due to their great influence on the estimated coefficients, reducing the number of observations from 29 to 26. The exogenous variables are the same used in explaining the initial abnormal returns, adding the latter one, initial abnormal returns, and dropping the timing variable before proceeding with the regression models. 
Table 8. Multivariate Cross-Sectional Regression Analysis for the Determinants of Aftermarket Abnormal Returns of IPOs

\begin{tabular}{|c|c|c|c|c|}
\hline \multicolumn{5}{|c|}{ Panel A: Abnormal Results Model } \\
\hline \multirow{3}{*}{$\begin{array}{l}\text { Independent } \\
\text { variables }\end{array}$} & \multicolumn{4}{|c|}{ Dependent variable: Aftermarket abnormal returns } \\
\hline & \multicolumn{2}{|c|}{ Cumulative abnormal returns (CAR) } & \multicolumn{2}{|c|}{ Buy-and hold abnormal returns (BHAR } \\
\hline & Coefficient & $t$-statistic & Coefficient & $t$-statistic \\
\hline Intercept & 0.64 & $(1.24)$ & 0.65 & $(1.14)$ \\
\hline EXANTE & 10 & $(-1.05)$ & -11.72 & $(-1.14)$ \\
\hline PSO & -0.39 & $(-0.6)$ & -0.56 & $(-0.77)$ \\
\hline MV & 65.73 & $(3.6)^{\star \star \star}$ & 40.21 & $(1.98)^{*}$ \\
\hline OVRS & 0.001 & $(1.31)$ & 0.0008 & $(0.7)$ \\
\hline CONT & -0.57 & $(-2.13)^{\star \star}$ & -0.15 & $(-0.49)$ \\
\hline IND & -1.1 & $(-4.51)^{* * *}$ & -0.71 & $(-2.59)^{* *}$ \\
\hline ar & 0.03 & $(0.51)$ & -0.04 & $(-0.73)$ \\
\hline$R^{2} \%$ & 43.9 & & 40.16 & \\
\hline Adj. $R^{2} \%$ & 25.19 & & 20.22 & \\
\hline F-value & $2.35^{*}$ & & $2.01^{*}$ & \\
\hline No. of observations & 26 & & 26 & \\
\hline
\end{tabular}

Panel B: Capital asset pricing model (CAPM)

\begin{tabular}{|c|c|c|c|c|}
\hline \multirow{3}{*}{$\begin{array}{l}\text { Independent } \\
\text { variables }\end{array}$} & \multicolumn{4}{|c|}{ Dependent variable: Aftermarket abnormal returns } \\
\hline & \multicolumn{2}{|c|}{ Cumulative abnormal returns (CAR) } & \multicolumn{2}{|c|}{ Buy-and hold abnormal returns (BHAR) } \\
\hline & Coefficient & $t$-statistic & Coefficient & t-statistic \\
\hline Intercept & 0.37 & $(0.75)$ & 0.4 & $(0.75)$ \\
\hline EXANTE & -8.34 & $(-0.94)$ & -3.39 & $(-0.35)$ \\
\hline PSO & -0.09 & $(-0.14)$ & -0.33 & $(-0.5)^{\prime}$ \\
\hline MV & 37.78 & $(2.16)^{\star \star}$ & 21.7 & (1.15) \\
\hline OVRS & 0.002 & $(1.63)$ & 0.001 & $(0.91)$ \\
\hline CONT & -0.56 & $(-2.17)^{\star \star}$ & -0.09 & $(-0.34)$ \\
\hline IND & -0.54 & $(-2.29)^{\star \star}$ & -0.31 & $(-1.21)$ \\
\hline$a r$ & -0.007 & $(-0.15)$ & -0.07 & $(-1.27)$ \\
\hline$R^{2} \%$ & 34.72 & & 33.66 & \\
\hline Adj. $R^{2} \%$ & 12.69 & & 11.55 & \\
\hline$F$-value & 1.6 & & 1.52 & \\
\hline No. of observations & 26 & & 26 & \\
\hline
\end{tabular}

54. The aftermarket performance of GCC IPOs over a one-year period using different methods and models seems to be driven by market volatility, market sentiment (country), and industry classification (Table 8). Particularly interesting is the sign on the parameters for market sentiment and industry classification - both variables have negative signs which is consistent with the expected results. That means that firms that went public in booming markets and from regulated industries provided investors with negative long-run abnormal returns. These results support the findings of the parametric $t$-statistics and the nonparametric Mann-Whitney test, and are consistent with the findings from the initial abnormal return regression that indicates that investors in the GCC were mainly driven by the trend of the market and the economic activities in which their firms operate. 


\section{SUMMARY AND CONCLUDING REMARKS}

55. The paper examines the short- and long-run abnormal returns of 47 IPOs in the GCC equity markets during 2000-06 and their determinants. The results show that GCC IPOs yielded economically and statistically significant initial abnormal returns in line with the underpricing phenomenon of IPOs, which has been widely documented in the literature. Initial abnormal returns averaged 290 percent, well above those documented for other industrial and emerging markets. The performance of IPOs in aftermarket trading was mixed: positive average abnormal returns (between 275 and 280 percent) were documented if initial returns are included, whereas aftermarket performance turns negative (ranging from -23 percent to -50 percent) vis-à-vis the benchmark portfolio when initial returns are excluded. Therefore, a strategy of investing one dollar in IPOs at the end of the first trading day and holding it for one year would have left an investor with only 77 to 50 percent of the return of each dollar invested in GCC stock exchange general indices. This is broadly in line with other empirical studies on the behavior of the IPO market, which find that investors are initially over-optimistic about IPO performance.

56. The results of the multivariate cross-sectional regression models used to identify the determinants of the IPOs' initial and aftermarket abnormal returns indicate that GCC investors tended to be widely driven by market excitement (bullish or bearish) and the regulated nature of the IPO's economic sector, rather than by risk, expected demand for the stock, or the firm's "signaling."

57. Investors seemed generally over-optimistic during the subscription period and shortrun trading, which resulted in short-run stock prices above their (fair) equilibrium level, and negative abnormal long-run returns when misvaluations were corrected over time. However, it is uncertain to what extent has this investor over-optimism affected the existence of positive abnormal returns of IPOs in the short run and negative abnormal performance in the long run, since the time period of the analysis may also have affected this outcome. This is so because the majority of the IPOs included in the multivariate regressions took place during booming years (particularly 2005), while their one-year anniversary coincided with a severe correction in most GCC equity markets. ${ }^{29}$ Further research extending the sample period beyond one year will provide additional evidence on some of the patterns of IPO performance in the GCC equity markets. Also, widening the study to other equity markets will increase the pool of information and obtain more conclusive results on the determinants of IPOs aftermarket abnormal returns in the GCC. Further work is needed before some of the results of this paper can be interpreted more generally.

\footnotetext{
${ }^{29}$ As noted in footnote 23, the TIM dummy is excluded from the specification of equation (19) and, thus, the model does not allow for controlling on the period of the IPOs in the analysis of the determinants of abnormal aftermarket returns. However, the results of the model for initial abnormal results estimated through equation (18), presented in Table 6, show that TIM is a significant determinant for initial abnormal returns. Therefore, it could be expected that TIM also is significant in determining the aftermarket abnormal returns of IPOs.
} 
58. Despite the limitations of the paper, some policy recommendations could be derived from its findings. Since one of the main drives of abnormal results is the booming nature of the markets, measures to avoid market volatility would help to smooth aftermarket abnormal negative results. The structural shortcomings of the GCC equity markets and, in particular, the lack or small size of traditional institutional investors, the small free-float of shares, the lack of a widespread financial culture among retail investors, and the relatively new and incomplete regulatory and supervisory frameworks, explain to a large extent the difficulty of the markets in performing adequately its price formation function. Therefore, emphasis should be put in creating incentives for the development of institutional investors, ${ }^{30}$ with a long-term investment profile, that could counterbalance the short-term euphoria of booming markets. Efforts to educate retail investors and to create professional and accountable financial advisory firms will go a long way in eliminating the over-optimism that has characterized investors in the GCC. Finally, the regulatory authorities should strengthen regulations and ensure compliance from investors, intermediaries and listed companies, to ensure that complete and accurate information is provided to investors and severely penalize price manipulation practices.

59. The policy of underpricing IPOs as a means to share oil wealth with the population at large may have some negative side effects on the stability of the equity market. The findings of the paper confirm that the regulated or unregulated nature of the sector of the companies undergoing IPOs is a key determinant of abnormal returns. This shows the important impact on market prices of this wealth distribution policy. The overbidding on these IPOs somehow extends to the rest of the market, either because of an euphoria-effect that leads to a widespread expectation of gains across-the-board, or because some investors take the general price index as a reference for investments and the IPOs of large companies have a substantial immediate effect in the increase in the general index. ${ }^{31}$ Therefore, alternative mechanism should be considered for the distribution of the wealth that does not interfere with the price formation mechanism of the equity market.

\footnotetext{
${ }^{30}$ This will include opening investment the markets to foreign investment, which is currently limited to a few countries and economic sectors.

${ }^{31}$ See paragraph 34 above.
} 


\section{References}

Aggarwal, R., Leal, R., and Hernandez, L., (1993), "The Aftermarket Performance of Initial Public Offerings in Latin America," Financial Management, 22 (1), 43-53.

Agarwal, S., Liu, C., and Rhee, S., (Forthcoming), "Investor Demand for IPOs and Aftermarket Performance: Evidence from the Hong Kong Stock Market," Journal of International Financial Markets, Institutions and Money.

Allen, F., and Faulhaber, G., (1989), "Signaling by Underpricing the IPO Market," Journal of Financial Economics, 23, 303-23.

Aussenegg, W., (2000), "Privatization Versus Private Sector: Initial Public Offerings in Poland," Multinational Finance Journal, 4 (1-2), 69-99.

Barber, B., and Lyon, J., (1997), "Detecting Long-Run Abnormal Stock Returns: The Empirical Power and Specification of Test Statistics", Journal of Financial Economics, 43 (3), 341-72.

Beatty, R.P., and Ritter, J.R., (1986), "Investment Banking Reputation and the Underpricing of Initial Public Offerings," Journal of Financial Economics, 15, 213-32.

Brav, A., and Gompers, P., (1997), "Myth or Reality? The Long-Run Underperformance of Initial Public Offerings: Evidence from Venture Capital and Non-Venture CapitalBacked Companies," Journal of Finance, 52 (5), 1791-1822.

Choi, S-D., and Nam, S-K., (1998), "The Short-Run Performance of IPOs of Privately- and Publicly-Owned Firms: International Evidence," Multinational Finance Journal, 2 (3), 225-44.

Derrien, F., and Womack, K., (2003), "Auctions vs. Bookbuilding and the Control of Underpricing in Hot IPO Markets," Review of Financial Studies, 16, 31-61.

Dewenter, K., and Malatesta, P., (1997), "Public Offerings of State-Owned and PrivatelyOwned Enterprises: An International Comparison", Journal of Finance, 52 (4), 165979.

Grinblatt, M., and Hwang, C.Y., (1989), "Signaling the Pricing of New Issues," Journal of Finance, 44 (2), 393-420.

How, J., Izan, H., and Monroe, G., (1995), "Differential Information and the Underpricing of Initial Public Offerings: Australian Evidence," Accounting and Finance, 35 (1), 87106.

International Monetary Fund, International Financial Statistics, Washington DC (series 2001-2006). 
Jaskiewicz, P., Gonzalez, V., Menendez, S., and Schiereck, D., (2005), "Long-Run IPO Performance Analysis of German and Spanish Family-Owned Businesses," Family Business Review, 18 (3), 179-202.

Jelic, R., and Briston, R.J., (1999), "Hungarian Privatization Strategy and Financial Performance of Privatized Companies", Journal of Business Finance and Accounting, 26 (9-10), 1319-57.

Jenkinson, T., and Mayer, C., (1988), "The Privatization Process in France and the UK," European Economic Review, 32, No. (2-3), 482-90.

Jones, S., Megginson, L., Nash, R., and Netter, J., (1999), "Share Issue Privatizations as Financial Means to Political Economics Ends", Journal of Financial Economics, 53 (3), 217-53.

Keloharju, M., (1993), "The Winner's Curse, Legal Liability, and the Long-Run Price Performance of Initial Public Offerings in Finland," Journal of Financial Economics, 34 (2), 251-77.

Kothari, S., and Warner, J., (1997), "Measuring Long-Run Horizon Security Price Performance," Journal of Financial Economics, 43 (3), 301-40.

Leleux, B., and Muzyka, D., (1997), "European IPO Markets: The Post-Issue Performance Imperative," Entrepreneurship Theory and Practice, 21, 111-18.

Levis, M., (1993), "The Long-Run Performance of Initial Public Offerings: The UK Experience 1980-1988," Financial Management, 22 (1), 28-41.

Loughran, T., Ritter, J.R., and Rydqvist, K. (1994), "Initial Public Offerings: International Insights," Pacific-Basin Finance Journal, 2, 165-99.

Lyon, J., Barber, B., and Tsai, C., (1999), "Improved Methods for Tests of Long-Run Abnormal Stock Returns," Journal of Finance, 54 (1), 165-201.

Menyah, K., and Paudyal, K., and Inganyete, C., (1995), "Subscriber Return, Underpricing, and Long-Term Performance of UK Privatization Initial Public Offers," Journal of Economics and Business, 47 (5), 473-95.

Morck, R., Shleifer, A., and Vishny R., (1990), “The Stock Market and Investment: Is the Market a Sideshow?" Brookings Papers on Economic Activity, 2, 157-216.

Omran, M., (2005), "Underpricing and Long-Run Performance of Share Issue Privatizations in the Egyptian Stock Market," Journal of Financial Research, 28 (2), 215-234. 
Paudyal, K., Saadouni, B., and Briston, R.J., (1998), "Privatization Initial Public Offerings in Malaysia: Initial Premium and Long-Term Performance," Pacific-Basin Finance Journal, 6, 427-51.

Perotti, E., (1995), "Credible Privatization," American Economic Review, 85, (4), 847-59.

Perotti, E., and Guney, S., (1993), "Successful Privatization Plans: Enhanced Credibility Through Timing and Pricing of Sales," Financial Management, 22(1), 84-98.

Ritter, J. R, (1984), "The Hot Issue Market," Journal of Business, 57, 215-40. ., (1991), "The Long-Run Performance of Initial Public Offerings," Journal of Finance, 46 (1), 3-27.

Rock, K., (1986), "Why New Issues are Underpriced," Journal of Financial Economics, 15, 187-212.

Welch, I., (1989), "Seasoned Offerings, Imitation Costs, and the Underpricing of Initial Public Offerings," Journal of Finance, 44, (2), 421-449.

White, H., (1980), "A Heteroskedastic-Consistent Covariance Matrix Estimator and a Direct Test of Heteroskedasticity," Econometrica, 48, 817-38. 


\section{APPENDix I: Detailed Information On the Performance of IPOS By COUNTRY}

This appendix table provides information on initial returns and buy-and-hold aftermarket performance of the IPOs over a one-year period excluding and including initial returns. Information is provided on each country and each IPO, and a simple average return of each country.

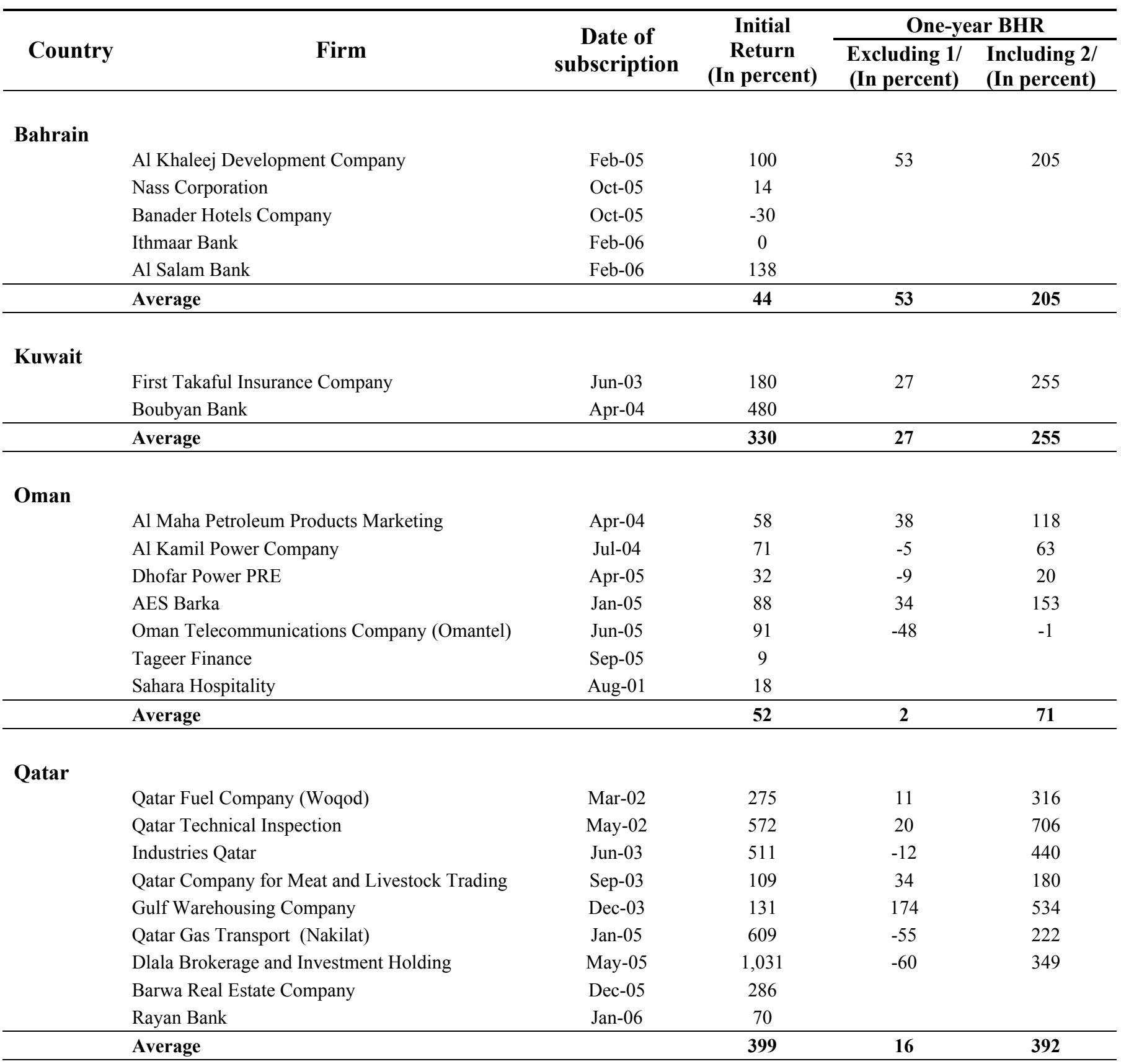




\section{Saudi Arabia}

Saudi Telecom Company

Sahara Petrochemical Company

$\begin{array}{cccc}\text { Jan-03 } & 39 & 77 & 147 \\ \text { Jun-04 } & 200 & 204 & 812 \\ \text { Dec-04 } & 500 & 139 & 1,336 \\ \text { Jan-05 } & 81 & 87 & 239 \\ \text { Mar-05 } & 1,430 & 2 & 1,462 \\ \text { May-05 } & 94 & -39 & 18 \\ \text { Jul-05 } & 53 & 39 & 112\end{array}$

Almarai Company

National Petrochemicals Company (Yansab)

Dec-05

1,120

Aldrees Petroleum and Transport Services

Company

Jan-06 87

Saudi Research and Marketing Group

Apr-06

106

Saudi Paper Manufacturing

May-06

130

Average

349

73

590

UAE

Dubai Islamic Insurance and Reinsurance

Company

Amlak Finance

Arab Technical Construction

Arab International Logistics Company

Al Dar Properties

Emirates Foodstuff

Finance House

Abu Dhabi National Energy

Sorouh Real Estate Company

RAK Properties

Dana Gas

Aabar Petroleum Investments Company

Emirates Integrated Telecommunications Co.

$\begin{array}{cc}\text { Oct-02 } & 387 \\ \text { Jan-04 } & 152 \\ \text { Aug-04 } & 392 \\ \text { Mar-05 } & 294 \\ \text { Oct-04 } & 650 \\ \text { Jan-05 } & 641 \\ \text { Apr-04 } & 1,28 \\ \text { Jul-05 } & 611 \\ \text { May-05 } & 564 \\ \text { Apr-05 } & 320 \\ \text { Sep-05 } & 307 \\ \text { Apr-05 } & 421 \\ \text { Mar-06 } & 125 \\ \end{array}$

473

\begin{tabular}{ccc}
387 & 17 & 473 \\
152 & 67 & 320 \\
392 & 49 & 633 \\
294 & -12 & 250 \\
650 & 19 & 792 \\
641 & -71 & 117 \\
1,281 & -31 & 851 \\
611 & -60 & 185 \\
564 & & \\
320 & & \\
307 & & \\
421 & & \\
125 & & $\mathbf{4 5 3}$ \\
$\mathbf{4 7 3}$ & $\mathbf{- 3}$ & \\
\hline
\end{tabular}

1/ BHR Excluding refers to one-year buy-and-hold return excluding initial returns.

2/ BHR Including refers to one-year buy-and-hold return including initial returns. 